\title{
BOHDAN OSADCZUK JAKO RZECZNIK EUROPEJSKIEGO DIALOGU CYWILIZACYJNEGO
}

\author{
Bohdan Osadchuk as a Spokesman \\ of the European Dialogue of Civilisations
}

The life and activity of the publicist, journalist and researcher Bohdan Osadchuk is a meaningful example of activities for the inter-civilisation dialogue. He was born in Galicia, which belonged to the Second Polish Republic, and he always treated Polish and Ukrainian cultures as his own. Osadchuk's efforts to strengthen Polish-Ukrainian relations and understanding, as well as his cooperation with Jerzy Giedroyc, editor-in-chief of the Paris-based journal Kultura [Culture], which was unique in terms of content and influence, were of particular importance. The author of this article has collected and analysed little-known and so far undiscovered facts and previously unavailable archival documents. Bohdan Osadchuk grew up in a multicultural environment. Professing liberal values, he condemned all chauvinism. He managed to combine the identity of a Ukrainian emigrant with that of a European democrat. For seventy years, he lived in Berlin (1941-2011), where he graduated from the university and became recognised as a journalist Alexander Korab. He was known under this pseudonym to readers of German newspapers and the oldest Swiss daily newspaper Neue Zürcher Zeitung for decades. For over half a century, he wrote for this authoritative newspaper about the events in the Soviet Union, Poland, Ukraine and the countries of the socialist bloc. Moreover, when actively cooperating with German radio and television, he introduced Polish and Ukrainian issues to the media discourse. The communist special services of the People's Republic of Poland and the Soviet Union hunted Bohdan Osadchuk, watched him and tried to recruit him. But he was playing his own game and was not fooled. This 
article also describes Osadchuk's scientific achievements that he gained as a professor at the Free University of Berlin (Freie Universität Berlin) and the Ukrainian Free University in Munich, as well as the author of fundamental publications. Moreover, the circumstances of the last years of Osadchuk's life, which ended in Poland, are presented for the first time.

Keywords: Polish-Ukrainian relations, Ukrainian Polonophile, Berlin, Germany, Poland, Ukraine, representative of three cultural circles, Kultura.

Był znany jako dziennikarz Alexander Korab. To właśnie pod tym pseudonimem znali go przez dekady czytelnicy niemieckich gazet oraz najstarszego (założonego w 1780 r.) dziennika szwajcarskiego „Neue Zürcher Zeitung". W tym opiniotwórczym piśmie w ciagu ponad półwiecza publikował materiały o wydarzeniach w ZSRR i krajach „obozu socjalistycznego”. Pisał także do innych periodyków w Niemczech. Został jednym $z$ najbardziej aktywnych publicystów polskiego emigracyjnego czasopisma „Kultura” redagowanego przez Jerzego Giedroycia, z którym razem konsekwentnie bronił idei polsko-ukraińskiego pojednania. Rzadziej wspomina się o tym, że był naukowcem, profesorem na dwóch uniwersytetach - Wolnym Uniwersytecie w Berlinie (Freie Universität Berlin) i Wolnym Uniwersytecie Ukraińskim w Monachium.

Był wysoce komunikatywna osoba o niewiarygodnym poczuciu humoru. Pomagało mu to w przezwyciężaniu trudnych sytuacji życiowych, zjednywało mu ludzi - w tym tych, którzy niekoniecznie podzielali jego poglądy i postawę. Do grona jego przyjaciół należeli: Zbigniew Brzeziński, Willy Brandt, Zhou Enlai, ściskał mu rękę i sprzyjał mu Josip Broz Tito. Był on nieformalnym doradca prezydentów Polski i Ukrainy Aleksandra Kwaśniewskiego i Łeonida Kuczmy.

W swojej działalności dziennikarskiej, naukowej i społecznej nieugięcie trzymał się własnej opinii i prezentował niezależna postawę, za co obwołano go „Atamanem”. Radzieccy przywódcy i propagandyści nienawidzili go za konsekwentny antykomunizm i bezstronne analizy wydarzeń w Europie Wschodniej i Związku Radzieckim. Działacz partyjny i państwowy ZSRR Nikita Chruszczow domagał się nawet od ambasadora Szwajcarii w Moskwie usunięcia Alexandra Koraba z dziennika „Neue Zürcher Zeitung”, co oczywiście nigdy nie zostało wykonane. Potężny wówczas Komitet Bezpieczeństwa Państwowego ZSRR opracował specjalna broszurę mająca na celu dyskredyta- 
cję publicysty i naukowca oraz podważenie jego reputacji (co również skończyło się niepowodzeniem).

Nie tylko widział na własne oczy upadek muru w Berlinie (w którym to mieście przeżył 70 lat), lecz także $z$ radościa powitał rozpad ZSRR, transformację ustrojowa $\mathrm{w}$ Polsce i proklamowanie niepodległości Ukrainy. Niejednokrotnie odwiedzał oba kraje i aktywnie publikował $\mathrm{w}$ periodykach. Najistotniejsze jednak, co zobaczył, to radykalna zmiana $\mathrm{w}$ relacjach polsko-ukrainskich, gdy po latach konfrontacji, wrogości i wzajemnej demonizacji przyszło pojednanie i współpraca. Pewnie właśnie to było najważniejszym rezultatem jego długiego, ciekawego, pełnego dramatyzmu, a niekiedy wręcz awanturniczego życia.

Mowa o Bohdanie Osadczuku. Miałem zaszczyt znać go przez wiele lat, współpracować $z$ nim, występować razem $z$ nim na różnych forach naukowych oraz podróżować. W 1998 roku zaprosiłem go do udziału w międzynarodowym dialogu ekspertów ds. podręczników szkolnych, a w 2000 roku jego artykuł otwierał tom, który opracowałem wspólnie z Magdalena Telus ${ }^{1}$. Poznawszy go, bez zastanowienia zaliczyłem go do grona tych, których określa się mianem „środkowoeuropejskich dżentelmenów". Chodzi o intelektualistów, którzy wyemigrowali na Zachód, uciekajacc przed Hitlerem lub Stalinem w latach 30. i 40. XX wieku oraz przed Chruszczowem w 1956 roku albo też przed Breżniewem $\mathrm{w}$ roku 1968. Wielu $z$ nich osiagnęło na Zachodzie sukces i uznanie. O ich polskim, czeskim rosyjskim lub jakimkolwiek innym pochodzeniu pamiętaja obecnie nieliczni.

Jak dotąd nie istnieje żadna kompletna biografia naukowa Bohdana Osadczuka, tylko niektóre poszczególne rozprawy dotyczą tych lub innych aspektów jego działalności ${ }^{2}$. On sam jednak zdążył dość szczegółowo opowiedzieć o swoim życiu, co też zostało utrwalone ${ }^{3}$.

1 Zob. B. Osadčuk, Na perehrestâh časìv, w: Ukraïns'ka isstorična didaktika. Mìžnarodnij dìalog (fahiveì rìznih kraïn pro sučasnì ukraïns'kì pìdručniki $z$ istoriï), vìdp. red. M. Telus, Û. Šapoval, Geneza, Kiïv 2000, s. 11-14.

2 Zob. np. I. Hofman, Tematy polsko-ukrainskie Bohdana Osadczuka w paryskiej „Kulturze”, „Przegląd Politologiczny” 2011, r. 16, nr 3, s. 185-194; P.Z. Lodin, Podolannâ neg'ativnih mîfiv ì stereotipiv ukraïns'ko-pol's'kih vìdnosin u političnìj dîal'nostì Bogdana Osadčuka, "Gileâ: naukovij vìsnik” 2015, nr 103, s. 347-351 i in.

3 Zob. np. M. Čeh, Rozkrïmo karti, panove! - rozmova z prof. Vil'nogo unìversitetu $v$ Berlìnì Bogdanom Osadčukom, „Zustrìči” 1990, nr 1-2, s. 24-32; B. Osadczuk, Włoch z Kolomei, rozm. przepr. R. Januszewski i J. Strękowski, „Rzeczpospolita - Plus Minus”, 5 VIII 2000, nr 182 (5652), s. 2-3; Wiek ukraińsko-polski. Rozmowy z Bohdanem Osadczukiem, red. B. Kerski, A.S. Kowalczyk, współpraca K. Zastawny, Wydawnictwo UMCS, Lublin 2001; Ein ukrainischer Kosmopolit mit Berliner Adresse. Gespräche mit Bohdan Osadczuk 
W 2006 roku w Kijowie odbyła się konferencja międzynarodowa poświęcona Jerzemu Giedroyciowi. Bohdan Osadczuk wziął w niej udział, a jego wystapienia obfitowały we wspomnienia ${ }^{4}$. Jeszcze gdy żył wydano jego wybrana publicystykę ${ }^{5}$ oraz korespondencję $z$ Jerzym Giedroyciem ${ }^{6}$.

Bardzo dużo działały i nadal działają na rzecz zachowania pamięci o Bohdanie Osadczuku i opracowania jego dorobku Bogumiła Berdychowska i Ola Hnatiuk. Między innymi w 2007 roku pod ich redakcja ukazała się praca zbiorowa Polska. Ukraina. Osadczuk ${ }^{7}$. Zbiór ten, którego powstanie zostało zainspirowane obchodami jubileuszu 85-lecia Bohdana Osadczuka w 2005 roku, zawiera rozprawy naukowe poświęcone przeszłości i współczesności Polski i Ukrainy głównie w XX wieku, a także teksty dziennikarskie i literackie. To wydanie jest cenne także ze względu na umieszczona w nim bibliografię publikacji Bohdana Osadczuka w języku polskim za lata 1952-2005 opracowaną przez Annę Lazar ${ }^{8}$.

W 2012 roku (rok po śmierci Bohdana Osadczuka) dokonano bodajże najbardziej szeroko zakrojonego zbiorowego wysiłku ukazania jego sylwetki. Mowa o publikacji Ukraiński polonofil. Pamięci Bohdana Osadczuka wydanej pod red. Iwony Hofman'. Pierwsza część tomu zawiera artykuły o samej postaci dotyczace różnych okresów i aspektów jego życia i działalności. Na drugą część złożyły się artykuły o rozmaitej problematyce poświęcone jego pamięci.

(Alexander Korab), Fibre Verlag, Osnabrück 2004; R. Kabačij, Kul'tovij dîasporânin. Profesor Bogdan Osadčuk dilit'sâ mìrkuvannâmi pro nìmec'ko-rosijs'ku družbu, ukraïns'kij nacìonalìzm ì zgaduê burhlivu molodist', „Ukraïns'kij tižden'” 2008, nr 50, http://tyzhden.ua/Publication/2413 [dostęp: 23 lipca 2020]; Polska i Ukraina. Rozmowy z Bohdanem Osadczukiem, rozm. przepr. B. Kerski, A.St. Kowalczyk, współpraca K. Zastawny, Kolegium Europy Wschodniej im. Jana Nowaka-Jeziorańskiego, Wrocław 2008 (w 2009 r. książka ta ukazała się w tłumaczeniu na język ukraiński w Kijowie, zob. B. Kers'kij, A. St. Koval'čik, Rozmovi $z$ Bogdanom Osadčukom, per. $z$ pol., Duh i Litera, Kiïv 2009) i in.

4 Zob. Evropa - minule ì maỉbutnê - vizìì' ta revizìi': Materiâli mižnarodnoì' konferencì̀' pam 'âtì Êži G'edroǐcâ, Kiïv, 24-26 XI 2006 r., red. O. Gnatûk, A. Mokrousov, Kritika, Kiïv 2009, s. 27-28, 61-62, 162-163, 228.

5 Zob. B. Osadczuk, Ukraina, Polska, świat, wybrał i przedmowa opatrzył A.St. Kowalczyk, Wydawnictwo Pogranicze, Sejny 2000; B. Osadčuk, Ukraïna, Pol'ŝa, svit. Vibranì reportaži ta stattì, Smoloskip, Kiïv 2001; B. Osadczuk, Niepodległa Ukraina: wybór szkiców, artykułów i rozmów (1991-2006), Wydawnictwo Pogranicze, Sejny 2006.

6 J. Giedroyc - B. Osadczuk, Listy 1950-1970, w: J. Giedroyc, Emigracja ukrainska, Listy 1950-1982, wybór, wstęp i przyp. B. Berdychowska, Czytelnik, Warszawa 2004.

7 Zob. Polska. Ukraina. Osadczuk, red. B. Berdychowska, O. Hnatiuk, Wydawnictwo UMCS, Lublin 2007.

8 Ibidem, s. 9-28.

9 Zob. Ukraiński polonofil. Pamięci Bohdana Osadczuka, red. I. Hofman, Wydawnictwo UMCS, Lublin 2012. 
Szereg publikacji ukazało się tuż po jego odejściu ${ }^{10}$. Jego imię zawsze jest wymieniane $\mathrm{w}$ publikacjach poświęconych działalności „Kultury” paryskiej lub normalizacji relacji polsko-ukraińskich ${ }^{11}$.

Na ogół jednak warto podkreślić ewidentny brak badań poświęconych postaci, o której jeszcze za życia redaktor naczelny niemiecko-polskiego czasopisma „Dialog” Basil Kerski napisał:

Osadczuk jest niezwykłym kosmopolitą: włada trzema językami - ukraińskim, polskim i niemieckim, w tych językach pisze i jest aktywnym uczestnikiem trzech obszarów kulturowych, co nawet dziś, w integrującej się Europie, stanowi rzadkie zjawisko. W XX wieku niebezpiecznie było być kosmopolitą. Nawet w naszych demokratycznych społeczeństwach, w których tak modne jest pojęcie „multikulti”, trudno być człowiekiem bez jednowymiarowej tożsamości narodowej, niemieszczącej się w prostych kategoriach nowoczesnej definicji narodów.

Trudno być człowiekiem niezależnym i poruszającym się w trzech kulturach. Kosmopolita często bywa traktowany jak obcy, ponieważ wnosi nowa perspektywę, która może kwestionować punkt widzenia dominujący w określonym obszarze kulturowym ${ }^{12}$.

Właśnie taka postacią był Bohdan Osadczuk.

\section{DROGA DO BERLINA}

Urodził się w dniu 1 sierpnia 1920 roku w Galicji, w mieście Kołomyja w obecnym obwodzie iwanofrankiwskim. W owych czasach Kołomyja, stolica Pokucia, znajdowała się w granicach II Rzeczypospolitej.

10 Zob. np. Â. Gricak, Džentl'men z Kolomï̈. Pam ‘âtì Bogdana Osadčuka, İstorična pravda, 20 X 2011, http://www.istpravda.com.ua/columns/2011/10/20/59875/ [dostęp: 23 lipca 2020]; O. Zvarič, Ukraïnocentričnij kosmopolit, „Ukraïna moloda”, 25 X 2011, <http:// www.umoloda.kiev.ua/number/1967/188/69984/> [dostęp: 23 lipca 2020]; T. Voznâk, Vidomij istorik Bogdan Osadčuk pomer u Pol'ŝi, Gazeta.ua, 20 X 2011, https://gazeta.ua/ articles/life/_vidomij-istorik-bogdan-osadchuk-pomer-u-polschi/405613 [dostęp: 23 lipca 2020]; Pomer vidomij ukraïns'kij istorik ì publìcist Bogdan Osadčuk, Ukrìnform, 20 X 2011 , <https://www.ukrinform.ua/rubric-society/1263422-pomer_vdomiy_ukranskiy_storik_ publtsist_bogdan_osadchuk_1050425.htm> [dostęp: 23 lipca 2020]; M. Čeh, Vidijšov ostannì otaman. Pam ‘âtì Profesora Bogdana Osadčuka, „Naše slovo”, 28 X 2011, https:// www.nasze-slowo.pl/vidiyshov-ostanniy-otaman/ [dostęp: 23 lipca 2020]; W. Jaruczyk, Zmarł ukrainski Giedroyc, „Monitor Wołyński”, 27 X 2011, s. 11 i in.

11 Zob. np. B. Bakuła, Polska i Ukraina w działalności „Kultury”, „Eurazja” 1995, nr 1; Prostìr svobodi: Ukrai'na na špal'tah pariz'koì' “Kul'turi”, vid. pìdg. B. Berdihovs'ka, per. z pol., Kritika, Kiïv 2005; O. Gnatûk, Pol's'ko-ukraìns'kiī dìalog: časopis „Kul'tura” ta ĭogo spadŝina, Centr gumanitarnih doslidžen' LNU, L'vìv, Smoloskip, Kiïv 2007; Giedroyc a Ukraina. Ukraińska perspektywa Jerzego Giedroycia i środowiska paryskiej „Kultury”, red. M. Semczyszyn i M. Zajączkowski, Instytut Pamięci Narodowej, Warszawa-Lublin-Szczecin 2014; Û. Polikovs'ka, Ukraïna na špal'tah pariz'koï „Kul'turi” v 1950-h rokah, „Mandrivec'” 2014, nr 2, s. 43-47.

12 B. Kerski, Z Kołomyi w świat, „Nowa Europa Wschodnia” 2010, nr 3-4, s. 182. 
Jego ojciec Jan Osadczuk pochodził z chłopów ukraińskich. Matka, Franciszka $z$ Bobińskich, miała pochodzenie mieszane, ukraińsko-słowackie. W rodzinie zawsze rozmawiano po ukraińsku.

W wieku lat 10 Bohdan znalazł się w centralnej Polsce. Jego ojciec był nauczycielem, czyli urzędnikiem państwowym zmuszonym stosować się do dyrektyw rządowych. Mając na celu polonizację Galicji i Wołynia, polskie władze przenosiły nauczycieli Ukraińców do centralnej Polski, a na ich miejsca kierowały nauczycieli nie władajacych językiem ukraińskim. Ze względu na pochodzenie ukraińskie i orientację (miał lewicowe poglądy i był członkiem Komunistycznej Partii Zachodniej Ukrainy) Jan Osadczuk został skierowany do powiatu pińczowskiego w województwie kieleckim, do wsi Boszczynek. Następnie szkołę przeniesiono do wsi Przybenice. Tutaj Osadczuk dorastał, jak później wspominał, „w otoczeniu polskich chłopów”"13. To właśnie stąd jego doskonała znajomość języka polskiego.

Znajomość i rozumienie kultury polskiej przyszły w dużym stopniu za sprawa tego, że w Boszczynku mieszkała dziedziczka sympatyzująca $z$ ukraińskim chłopczykiem, który na początku nie chciał chodzić do szkoły. Zachęcała go do czytania książek, uczyła języka francuskiego, dobrych manier oraz... bycia Polakiem. „Wychowywałem się - konstatował później Osadczuk - w dwóch światach: na pastwisku $z$ synami tamtejszych chłopów i we dworze u dziwaczki pani Śląskiej”" ${ }^{14}$. Kolejnym ważnym czynnikiem było to, że Osadczuk dorastał i wychowywał się w środowisku wielokulturowym, którym były miejsca jego dzieciństwa. W Kołomyi obok Ukraińców mieszkali Polacy, Żydzi, Niemcy, były tam też rodziny ormiańskie i greckie. To na zawsze uodporniło go na nacjonalizm i szowinizm, których nienawidził i nie przyjmował do końca życia.

Osadczuka oddano do państwowego gimnazjum w Pińczowie, gdzie zamieszkał $z$ kolegami na stancji. Było to jego pierwsze doświadczenie życia bez rodziców, którzy pozostali na wsi. Na krótko przed ukończeniem gimnazjum w 1938 roku został wydalony pod zmyślonym pretekstem. Rzeczywistym powodem było to, że obronił przed gimnazjalistami antysemitami zaszczutego przez nich kolegę $z$ klasy, Żyda o nazwisku Szapiro. Osadczuka wezwał do siebie i obraził ksiądz katecheta o nazwisku Piskorz. Nazwał chłopca „ukraińska świnią, na co dostał odpowiedź: „To ty jesteś faszystowską świnią!”15. Osadczuk

\footnotetext{
13 Cyt. za: Polska i Ukraina. Rozmowy z Bohdanem Osadczukiem..., s. 11.

14 Ibidem, s. 12.

15 Ibidem, s. 17.
} 
musiał wówczas $z$ czegoś się utrzymywać, a więc trzeba było zarabiać. Został więc dostawca raków do jednej z krakowskich restauracji.

Wybuchła II wojna światowa, Niemcy zajęli Polskę. Związek Radziecki po zmowie Hitlera i Stalina dokonał inwazji na wschodnie tereny II RP, obwołujac to „zjednoczeniem ziem ukraińskich”. Ojciec Osadczuka został zatrudniony jako tłumacz przy cukrowni w Kazimierzy Wielkiej, a następnie rodzina przeniosła się do Buska-Zdroju.

W styczniu 1940 roku w Krakowie zaczęła ukazywać się gazeta „Krakiwśki Wisti”. W piśmie tym Osadczuk znalazł informację, że dawny docent Uniwersytetu Jagiellońskiego Wołodymyr Kubijowycz ${ }^{16}$, który później został przewodniczacym Ukraińskiego Komitetu Centralnego ${ }^{17}$, zorganizował bezpłatne kursy maturalne. Wiosna 1940 roku Osadczuk udał się do Krakowa, ukończył wspomniane kursy, zdał maturę i wrócił do Buska-Zdroju.

$Z$ tym okresem związany jest pewien epizod biografii naszego bohatera, który wywarł decydujacy wpływ na jego antykomunistyczne przekonania. Jak już zostało wspomniane, jego ojciec był członkiem KPZU, więc Bohdan dość wcześnie zaczął czytać polska prasę lewicową, a także organ Komunistycznej Partii Niemiec na emigracji „Die Rote Fahne” („Czerwony Sztandar”) ${ }^{18}$. Dobrze opanował język niemiecki dzięki temu, że - jak wspominał - w jego gimnazjum była bardzo dobra germanistka ${ }^{19}$.

Poglądy ojca nie miały wpływu na syna, chociaż obaj zgadzali się w ocenie antyukraińskiej polityki przedwojennej Polski. Zgadzali się

${ }^{16}$ Wołodymyr Kubijowycz (1900-1985) - historyk, geograf, wydawca, działacz społeczno-polityczny, organizator wydania i redaktor naczelny Encyklopedii Ukrainoznawstwa. To fundamentalne dzieło $z$ zakresu ukrainistyki powstało pod auspicjami europejskiego oddziału Towarzystwa Naukowego im. Szewczenki z siedzibą w Sarcelles (Francja). Autor fundamentalnego studium Geografia Ukrainy i przylegajacych ziem (1938); od 1940 r. Przewodniczaccy Ukraińskiego Komitetu Centralnego.

17 Ukraiński Komitet Centralny (UKC) - jedyna w latach 1940-1945 organizacja społeczna zrzeszająca Ukraińców w utworzonym przez nazistów na terytorium Polski Generalnym Gubernatorstwie (GG). Terytorium to postrzegano nie jako tereny okupowane, lecz jako cześć „Wielkiej Rzeszy Niemieckiej”. UKC był oficjalnie uznany i kontrolowany przez władze niemieckie. Na czele UKC stał W. Kubijowycz. Ze względu na to, że wszystkie inne instytucje ukraińskie w GG zostały zlikwidowane przez władze hitlerowskie, zakres działalności UKC obejmował prawie wszystkie sfery życia Ukraińców w GG, z wyjątkiem politycznej. Ponadto UKC reprezentował Ukraińców wobec władz niemieckich. Działalność i struktura UKC wyznaczane były przez polityke okupacyjna i specyficzny charakter reżimu nazistowskiego (szerzej na ten temat zob. V. Kubijovič, Ukraïncì v G'eneral'nij Guberniï (1939-1941), Vidavnictvo Mikoli Denisûka, Čikag'o 1975; V. Kubìjovič, Menì 85, Molode žittâ, Pariž Mûnhen 1985.

18 „Die Rote Fahne” - dziennik niemiecki ukazujacy się w latach 1918-1939, założony przez Karola Liebknechta i Różę Luksemburg. Od grudnia 1918 r. był organem prasowym Komunistycznej Partii Niemiec.

19 Zob. Polska i Ukraina. Rozmowy z Bohdanem Osadczukiem..., s. 26. 
również co do tego, że niczego dobrego nie należało oczekiwać po nazistach. Wielu Ukraińców wstapiło wówczas do służby w organizacjach lub instytucjach utworzonych przez Niemców. Było tam wielu emigrantów $z$ Galicji, których Niemcy również przyjmowali. Osadczuk starszy, jak zostało wcześniej powiedziane, pracował jako tłumacz w cukrowni. Przyczyna jego współpracy była bardzo prosta: po porozumieniach między Niemcami a ZSRR bardzo bał się ekstradycji, że Niemcy wydadza go „Sowietom”. Dla niego oznaczałoby to koniec, ponieważ Komunistyczna Partia Zachodniej Ukrainy była partia represjonowanych - jej przywództwo i członków jeszcze w 1938 roku obwołano w stalinowskim ZSRR zdrajcami i „faszystowskimi sprzedawczykami"20.

Osadczuk młodszy słuchał lwowskiego radia (czyli już radzieckiej propagandy) i czytał gazety o orientacji lewicowej, które rozpisywały o przewagach „socjalistycznego raju”. W końcu uwierzył, że może warto jednak wrócić do rodzinnych miejsc. W tym czasie do Buska przyjechała radziecka misja repatriacyjna, do której Osadczuk udał się, nie znając języka rosyjskiego. Oto co wspominał na ten temat:

Za stołem siedział kwadratowy generał sowiecki z NKWD, a dokoła hitlerowcy z SD. Enkawudzista spytał: „Wasza familia?”. Odpowiedziałem z przekonaniem, że jestem „sam, bez familii”. A on: „Szto, wy nie panimajetie pa ruski? Wy otkuda?”. „A szczo ce znaczyt' otkuda? - zdziwiłem się. - To nie jest ukraińska misja?" Zaczął na mnie krzyczeć, że jestem burżuazyjnym nacjonalista i trzeba mnie aresztować. Niemcy wybuchnęli śmiechem, zdążyłem stamtąd wyjść o własnych siłach. Misja wyjechała, a moja miłość do Sowietów na tym etapie zakończyła się definitywnie ${ }^{21}$.

Następnie w życiu Osadczuka nie działo się nic szczególnego, dopóki nie przeczytał w piśmie „Krakiwśki Wisti” ogłoszenia o tym, że Ukraiński Komitet Społeczny w Chełmie poszukuje współpracowników. Tak oto Osadczuk znalazł się w Chełmie i został lokalnym korespondentem tegoż pisma, w którym regularnie publikował. To właśnie wtedy zaczął się dla Osadczuka, w sformułowaniu Oli Hnatiuk, jego „flirt $z$ nacjonalizmem" 22 . Nie został jednak ani banderowcem, ani melnykowcem, czyli nie był członkiem żadnej ze zwaśnionych frakcji Organizacji Ukraińskich Nacjonalistów (OUN).

20 Szerzej na ten temat zob. M.İ. Pančuk, „Bilì plâmi” geroï̌nogo lìtopisu: İz isstoriï Komunističnoï partiï Zahìnoï Ukraïni, Politvidav Ukraïni, Kiïv 1989; Û.Û. Slivka, Storìnki ìstoriï KPZU, Kamenâr, L'viv 1989.

21 Cyt. za: Polska i Ukraina. Rozmowy z Bohdanem Osadczukiem..., s. 27.

22 Zob: O. Hnatiuk, Nazywali go Atamanem..., w: Ukraiński polonofil. Pamięci Bohdana Osadczuka..., s. 32. 
Kiedy powstał Ukraiński Komitet Pomocy ${ }^{23}$, zaprzyjaźnił się i współpracował ze Stepanem Skrypnykiem, przyszłym Patriarchą Kijowskim i Całej Ukrainy Ukraińskiego Autokefalicznego Kościoła Prawosławnego (UAKP) ${ }^{24}$, świadcząc pomoc nie tylko chłopom ukraińskim oraz uchodźcom. Próbowano coś zrobić także dla jeńców z Armii Czerwonej, których po wybuchu w 1941 roku wojny niemiecko-radzieckiej osadzono za drutem kolczastym i skazano na śmierć $z$ powodu głodu i chorób.

Osadczuk widział, jak Niemcy zaczęli faworyzować Ukraińców, zwłaszcza pochodzacych $z$ Galicji, a jeszcze bardziej tych $z$ Austrii. Polacy $z$ kolei dostrzegali w tym obrazę i zagrożenie dla siebie, gdyż jedna z kategorii „ich obywateli” zaczęła dostawać przywileje od Niemców. Kiedy w Chełmie zorganizowano ukraińska szkołę, polscy radykałowie działający w podziemiu zastrzelili jej nauczyciela. Oto co później mówił o tym sam Osadczuk:

$Z$ jednej strony - rozbrat i rozłam wśród nacjonalistów ukraińskich, prowadzący niemal do krwawych porachunków. $Z$ drugiej strony polsko-ukraińska tragedia, która zaczęła się na Chełmszczyźnie, absolutnie przekonała mnie, że trzeba $z$ tym zjawiskiem walczyć, bo inaczej grozi nam perspektywa wzajemnych mordów w nieskończoność i sąsiedzi będą na tym wygrywali ${ }^{25}$.

Jest to bardzo ważna konkluzja, która następnie w życiu Bohdana Osadczuka wyznaczy jego miejsce w normalizacji stosunków polsko-ukraińskich. W owym czasie miał miejsce jeszcze jeden istotny moment dla przyszłości naszego bohatera: od wspomnianego Skrypnyka dowiedział się o Jerzym Giedroyciu, redaktorze poczytnych czasopism „Bunt Młodych” i „Polityka”26. Spotkają się po dziesięciu latach.

${ }^{23}$ W Dystrykcie Galicja władze niemieckie zezwoliły na istnienie komitetów pomocy - jedynej formy organizacji dla wszystkich grup narodowościowych - Ukraińców, Polaków, Żydów. Korzystajac $z$ tego zezwolenia, Ukraińcy w GG wszędzie przekształcili już istniejące (lecz nie zalegalizowane przez władze niemieckie) komitety w dystryktach lub powiatach w Ukraińskie Komitety Pomocy. Koordynacją ich działalności zajmował się UKC. Wiosną 1941 r. UKC zrzeszał 26 Ukraińskich Komitetów Pomocy. Zob. T. Lapan, Diâl'nist' ukraïns'kih gromads'kih organizacìj na zahist stanoviŝa deportovanih ukraïns'kih robitnikiv u İIİ Rajhu, İstoričnij fakul'tet L'vivs'kogo nacional'nogo unìversitetu ìm. İ. Franka, http:// clio.lnu.edu.ua/wp-content/uploads/2015/02/3-1.pdf [dostęp: 23 lipca 2020].

${ }^{24}$ Stepan Skrypnyk (patriarcha Mścisław) (1898-1993) - wybitny działacz religijny, zwierzchnik Ukraińskiego Autokefalicznego Kościoła Prawosławnego w diasporze, w latach 1920-1921 był osobistym adiutantem Symona Petlury, w latach 1930-1939 - posel do Sejmu RP, gdzie bronił praw Ukraińców. W 1941 r. staną na czele Ukraińskiego Komitetu Pomocy w Chełmie. Szerzej na ten temat zob. A. Smirnov, Mstislav (Skripnik): gromads'ko-političnij ì cerkounij diâč. 1930-1944, Smoloskip, Kiïv 2008.

${ }_{25}$ Cyt. za: Polska i Ukraina. Rozmowy z Bohdanem Osadczukiem..., s. 29-30.

26 Gdzie indziej Osadczuk wspominał: „Czytałem jako szczeniak wypożyczony od sprzedawcy gazet w Pińczowie, garbusa-filozofa żydowskiego, "Bunt Młodych", a potem "Politykę". B. Osadczuk, Wyznania i zeznania ukrainskiego polonofila, „Kultura” 1977, nr 7-8, s. 205. 
Gdy w czerwcu 1941 roku wybuchła wojna ze Związkiem Radzieckim, w Ukraińskim Komitecie Pomocy w Chełmie prawie nie zostało młodych ludzi. Jeden $z$ weteranów emigracji petlurowskiej doradził Osadczukowi, by spróbował uciec przed wojna do stolicy III Rzeszy (w myśl powiedzenia, że najciemniej jest pod latarnia)).

\section{PRZEPROWADZKA DO NIEMIEC}

W owym czasie Ukraińców z Galicji (i tylko!) przyjmowano na uczelnie niemieckie. Osadczuk napisał do kilku uniwersytetów. Było to we wrześniu 1941 roku. Z Uniwersytetu Berlińskiego przyszła odpowiedź, że znajdzie się na liście studentów Wydziału Nauk o Zagranicy (Auslandswissenschaft) pod warunkiem złożenia egzaminu $z$ języka niemieckiego. W grudniu tegoż roku wyjechał do Berlina.

Podczas studiów w Berlinie Osadczuk najpierw otrzymywał stypendium od Komisji Organizacji Pomocy Studentom Ukraińskim, a później musiał zarabiać sam. Pracownik urzędu pracy, który wydawał mu zezwolenie, spojrzawszy w paszport Osadczuka, zapytał go, co to za miasto „Kolomea”. Tak po niemiecku Austriacy ochrzcili miasto w Galicji - die Stadt in Galizien - wyjaśnił Osadczuk. Niemieccy urzędnicy zaczęli kpić ze studenta ,ignoranta”, przecież Galicja znajduje się w Hiszpanii, a miasto Kolomea - we Włoszech. Po czym przybili mu pieczątkę: Italien. W 1945 roku, gdy już Armia Czerwona będzie urządzała w Berlinie kontrole, „przemiana” z Ukraińca we Włocha uratuje go. Nie mając wiarygodnych dokumentów, przez pewien czas będzie podawał się za Włocha ${ }^{27}$.

Osadczuk studiował u prof. Albrechta Haushofera - syna Karla Haushofera, twórcy geopolityki ${ }^{28}$. Haushofer $j$ r. należał do uczestników najpoważniejszego zamachu na Adolfa Hitlera latem 1944 roku. Gdyby wszystko się udało, Haushofer miał zostać ministrem spraw zagranicznych w rzadzie opozycji antyhitlerowskiej. Zamach jednak skończył się niepowodzeniem, hitlerowcy aresztowali Haushofera. W 1945 roku zastrzelono go podczas spaceru w więzieniu. Dlatego

${ }_{27}$ Zob. Polska i Ukraina. Rozmowy z Bohdanem Osadczukiem..., s. 63, 65-66; O. Hnatiuk, Nazywali go Atamanem..., s. 33.

${ }^{28}$ Karl Haushofer (1869-1946) - geograf, socjolog, założyciel niemieckiej szkoły geopolityki. Podczas pobytu Adolfa Hitlera i Rudolfa Hessa w więzieniu po puczu monachijskim z 1923 r. Haushofer prowadził dla nich wykłady z geopolityki. Uważa się, że Hitler przyswoił idee Haushofera dotyczace „przestrzeni życiowej” (Lebensraum). Szerzej na ten temat zob. H.H. Herwig, The Demon of Geopolitics: How Karl Haushofer "Educated" Hitler and Hess, Rowman \& Littlefield Publishers, Lanham 2016. 
tė̇ pracę dyplomowa poświęcona początkom i rozwojowi prasy na Ukrainie Zakarpackiej Osadczuk kończył pisać u znanego bałkanisty prof. Fritza Valjaveca ${ }^{29}$.

W Berlinie przed, podczas i po wojnie kwitło życie ukraińskie. Przykładowo od 1926 roku istniał Ukraiński Instytut Naukowy założony przy wsparciu dawnego hetmana Państwa Ukraińskiego Pawła Skoropadskiego ${ }^{30}$. Podczas II wojny światowej, wspominał Osadczuk:

[...] mieliśmy własne, odrębne życie ukraińskie. Trudno ustalić, ilu nas było. Elita, którą stanowili wyżsi urzędnicy, lekarze, naukowcy i studenci, ludzie dawnej ukraińskiej prasy, była rozrzucona po rozmaitych instytucjach. [...] Studentów było około trzystu, ale pochodzili z Galicji, Wołynia, Bukowiny, Ukrainy Zakarpackiej, czyli dawnych państw niezależnych, a nie $z$ Reichskommissariatu [...] A po roku 1942 już w ogóle nie przyjmowano Ukraińców na uczelnie ${ }^{31}$.

Ukraińscy studenci, którymi kierował prof. Albrecht Haushofer, założyli organizację pod nazwą „Mazepiniec”. Obok Osadczuka weszli do niej jego najbliższy przyjaciel Iwan Łysiak-Rudnycki (w przyszłości znany historyk, politolog i jeden $z$ założycieli Canadian Institute of Ukrainian Studies w Edmonton), Omelan Pricak (w przyszłości wybitny orientalista, znawca wielu rzadkich języków i pierwszy dyrektor Harvard Ukrainian Research Institute) oraz niektóre inne osoby.

Członkowie wspomnianej organizacji studenckiej nie byli nacjonalistami, tylko raczej liberałami. Prowadzili np. agitację wśród studentów przeciwko wstępowaniu Ukraińców do dywizji SS „Galizien”. Haushofer nie wiedział o tym, ale po jego uwięzieniu jego studenci znaleźli się w polu zainteresowania Gestapo. Kilka razy Bohdanowi Osadczukowi udawało się uniknąć aresztowania, jego przyjaciele zaś wyjechali z Berlina.

${ }^{29}$ Fritz Valjavec (1909-1960) - historyk specjalizujący się w badaniach nad Europa Południowo-Wschodnia XX w. W 1941 r. był doradca politycznym i tłumaczem w Sonderkommando 10b der Einsatzgruppe D na Północnej Bukowinie i w Besarabii. Po powrocie do Berlina w lutym 1943 r. pracował jako profesor na Uniwersytecie Berlińskim, na wydziale, gdzie studiował B. Osadczuk.

30 Instytut miał za zadanie szerzenie wśród Niemców (m.in. w środowiskach akademickich) informacji na temat Ukrainy i narodu ukraińskiego, prowadzenie badań na temat dawnych i aktualnych relacji Ukrainy z krajami zachodnimi, w tym $z$ Niemcami, oraz wspomaganie ukraińskich studentów i naukowców w studiach i badaniach naukowych. Instytut przestał istnieć w 1945 r. Szerzej na ten temat zob. G.Û. Kaliberda, Naukovo-doslidnic'ka ta osvitnâ dîâl'nìst' Ukraïns'kogo naukovogo ìnstitutu u Berlìnì (1926-1945), www.rusnauka. com, http://www.rusnauka.com/5_NITSB_2009/Istoria/41208.doc.htm [dostęp: 23 lipca 2020].

31 Cyt. za: Polska i Ukraina. Rozmowy z Bohdanem Osadczukiem..., s. 68-69. 
Osadczuk pozostał w Berlinie. Tam w ostatnich miesiącach wojny założył fikcyjny Instytut Morza Czarnego. Instytut był zmyślony, ale korzyść przynosił realną. Na adres Instytutu Osadczuk dostawał podziemna prasę $z$ Warszawy oraz polskie wydawnictwa $z$ Londynu, gdzie znajdował się rząd RP na uchodźstwie. Przysyłano mu także dziennik „Neue Zürcher Zeitung” ze Szwajcarii, w którym później będzie publikował. W ten sposób był bardzo dobrze poinformowany. Podczas wojny aktywnie przesyłał korespondencje dla gazety „Wołyń”32 w Równem i dla „Krakiwśkich Wisti” (jeden $z$ jego ówczesnych pseudonimów to Jurij Czornomorski).

Berlin bombardowano. Ucierpiał wydział Osadczuka. W tym całym chaosie trafiły mu do rąk pieczątki i formularze, które mógł wykorzystywać w swoich interesach. Wspominał o tym:

Był chaos, a ja byłem panem. Nie było inwigilacji, kontroli politycznej nie odczuwałem i w gruncie rzeczy profesorowie zauważyli, że można sobie pozwalać prawie na wszystko i robić, co się chce. Historycy zaczęli mówić rzeczy mocno krytyczne. [...] Wiosna 1945 roku już nie można było swobodnie poruszać się środkami transportu, wprowadzono specjalne karty i przepustki. Metro jeździło rzadko, jeszcze rzadziej tramwaje. Sam wypisywałem sobie zaświadczenia dotyczące wykonywania szczególnie ważnych misji dla dobra III Rzeszy z zaznaczeniem, by okazywano mi wszelkiego rodzaju pomoc. I przystawiałem pieczątkę. To działało ${ }^{33}$.

Armia Czerwona prowadziła ofensywę i prof. Valjavec doradzał Osadczukowi, aby ten wyjechał $z$ Berlina. Pewien znajomy miał rodzinę w Poczdamie i Osadczuk wyjechał tam razem ze swoja przyszłą żona, Irena (Janina) Kuszkewycz, z zawodu lekarką, którą poznał w 1943 roku Tam też przeżyli wkroczenie Armii Czerwonej i po podpisaniu przez Niemcy kapitulacji postanowili wrócić do Berlina. Tam na Osadczuka czekała niespodzianka. Do berlińskiego mieszkania, w którym wcześniej mieszkał - a było to mieszkanie żydowskiej rodziny Gottschalków - pod jego nieobecność przychodzili poszukujacy go radzieccy oficerowie. Prawdopodobnie byli to funkcjonariusze Smiersza $^{34}$. Osadczuk zrozumiał, że znalazł się w poważnym niebezpieczeństwie i że teraz podawać się za Włocha, jemu już się nie uda.

32 Gazete „Wołyñ” wydawano w Równem w warunkach okupacji niemieckiej od września 1941 r. do stycznia 1944 r. Szerzej na ten temat zob. Û.G. Šapoval, İstorizm časopisu „Volin'” (1941-1944; 1991-2009 rr.), L'viv 2010.

${ }^{33}$ Cyt. za: Polska i Ukraina. Rozmowy z Bohdanem Osadczukiem..., s. 75-76.

${ }^{34}$ Smiersz (skrót od smiert' szpionam 'śmierć szpiegom') - nazwa niezależnych od siebie organizacji kontrwywiadowczych w ZSRR w okresie II wojny światowej oraz w pierwszym roku po wojnie. Chodzi o Główny Zarząd Kontrwywiadu „Smiersz” przy Ludowym Komisariacie Obrony ZSRR, na którego czele stał W. Abakumow i który podlegał bezpośrednio 
Trzeba było podjąć decyzję, jak żyć dalej. Ktoś inny w tej sytuacji mógłby wpaść w rozpacz, tylko nie Osadczuk, który przyzwyczaił się do patrzenia na przeciwieństwa losu $z$ ironicznym dystansem. Twardo postanowił nie wracać do Polski (gdzie Stalin umacniał swoje pozycje), ale przy tym nie chciał tracić więzi z Polska i Polakami, i uporczywie poszukiwał kontaktów, które mogłyby mu w tym pomóc. Wyjście $z$ tej sytuacji się znalazło. Wiosna 1945 roku do Berlina przyjechał jego znajomy żołnierz, któremu pomagał podczas wojny. Od niego Osadczuk dowiedział się, że redaktor naczelny warszawskiego „Kuriera Codziennego" (organ Stronnictwa Demokratycznego legalnie działającego w komunistycznej Polsce) poszukuje berlińskiego korespondenta. Po tygodniu dzięki protekcji znajomego, Osadczuk dostał legitymację korespondenta, pisał pod pseudonimem Jerzy Pont. W tym statusie często bywał w Polskiej Misji Wojskowej, która znajdowała się w brytyjskiej strefie okupacyjnej podzielonego przez aliantów Berlina ${ }^{35}$. Wysyłał swoją korespondencję za pomoca aparatu telegraficznego, który mógł znaleźć tylko tam. W Misji poznał jej szefa, pierwszego wojewodę olsztyńskiego i przedwojennego komunistę, gen. Jakuba Prawina. W lipcu 1946 roku Prawin dał Osadczukowi posadę referenta prasowego, który miał zajmować się analiza niemieckich gazet.

Bohdan Osadczuk miał antykomunistyczne przekonania, ale nie miał pieniędzy i solidnych dokumentów. Teraz dostał przyzwoicie

J. Stalinowi, oraz Oddział Kontrwywiadu Smiersz w NKWD ZSRR, na którego czele stał S. Juchimowicz i który podlegał ludowemu komisarzowi spraw wewnętrznych ZSRR Ł. Berii. Począwszy od końca 1943 r. aktywizowały się działania Smiersza odnośnie cywilów za granica ZSRR, głównie obywateli radzieckich i emigrantów. Wśród ofiar było wielu znanych działaczy ukraińskich. Pod koniec wojny i w pierwszym roku po wojnie Smiersz aktywnie sprawdzał byłych radzieckich jeńców wojennych i repatriantów w zorganizowanych $\mathrm{w}$ tym celu specjalnych obozach filtracyjnych. Za sprawą działań Smiersza na terenach państw Europy Srodkowej i Wschodniej internowano i więziono ponad 260 tys. osób poza jeńcami wojennymi. W maju $1946 \mathrm{r}$. organy kontrwywiadu wojskowego wcielono $z$ powrotem do systemu organów bezpieczeństwa państwowego. Szerzej na ten temat zob: L. Mlečin, KGB. Predsedateli organov gosbezopasnosti. Rassekrečennye sud'by, 3-e izd., dop., ZAO Izd-vo Centrpoligraf, Moskva 2001; V. Kodačigov (V. Kramar), „Smert' špionam!”, „Nezavisimaâ gazeta", 25 IV 2003; Lubânka. Organy VC̆K-OGPU-NKVD-NKGB-MGB-MVD-KGB. 1917-1991: Spravočnik, red. akad. A.N. Âkovlev, MFD, Moskva 2003 i in.

35 Polska Misja Wojskowa w Niemczech istniała w latach 1945-1990. Reprezentowała komunistyczna Polskę, początkowo miała sieć przedstawicielstw, kierowała innymi organami ówczesnej Polski na terytorium Niemiec, koordynowała takie kwestie, jak ściganie zbrodniarzy hitlerowskich czy rekwizycja mienia i odszkodowań dla Polski, a także zajmowała się repatriacja polskich obywateli. Po utworzeniu polskich ambasad w NRD (1949) i RFN (1974) Misja reprezentowała PRL tylko w Berlinie. Szerzej na ten temat zob. J.A. Radomski, Misje wojskowe na Zachodzie $z$ ramienia komunistycznych władz z Polski $i$ ich zadania 1945-1948, „Zeszyty Historyczne”, t. 12: Si vis pacem, para bellum: bezpieczeństwo i polityka Polski: ksiega jubileuszowa ofiarowana profesorowi Tadeuszowi Dubickiemu, red. R. Majzner, Wydawnictwo Akademii im. Jana Długosza, Częstochowa 2013, <http:// http://dlibra.bg.ajd.czest.pl:8080/Content/1749/22.pdf> [dostęp: 23 lipca 2020]. 
płatna pracę. Ponadto wyrobiono mu berliński dowód osobisty na podstawie tego, że mieszkał w Berlinie. Najważniejsza jednak, zdaniem Osadczuka, była legitymacja dziennikarska ${ }^{36}$. Polska Misja Wojskowa na kilka lat stanie się dla niego azylem.

Aby dostać pracę w Misji, „zmienił”, czyli sfalsyfikował własną biografię. Świadectwa tego przetrwały w Archiwum Instytutu Pamięci Narodowej w Warszawie. Bogumiła Berdychowska, która zbadała te dokumenty, ujęła to w sposób delikatny: Osadczuk „musiał skonstruować na nową swoją biografię" ${ }^{37}$. W przeciwnym razie - ze względu chociażby na jego pracę w Ukraińskim Komitecie Pomocy w Chełmie i jego publikacje w pismach „Krakiwśki Wisti” i „Wołyń” - wattpliwe, aby został przyjęty do pracy. W dniu 6 września 1946 roku Osadczuk własnoręcznie napisał życiorys, w którym m.in. zaznaczył, że w październiku 1941 roku wyjechał z Kołomyi do Warszawy na studia, ale został schwytany przez Niemców i wywieziony do prac przymusowych do Niemiec, gdzie następnie poddał się kuracji szpitalnej ze względu na zastarzała chorobę serca, a dopiero potem został korespondentem „Kuriera Codziennego" 38 .

Ciekawe jest to, że ten będący owocem wyobraźni Osadczuka życiorys, w którym prawdziwe były tylko miejsce urodzenia i imiona rodziców, na długie lata stał się jego oficjalna biografią. Cała jego kariera zawodowa została bowiem skonstruowana tak, by wydawała się jak najbardziej typowa dla losów Polaków podczas wojny. Poza tym natychmiastowe sprawdzenie jakichkolwiek informacji nie było możliwe ze względu na odległość Kołomyi od Berlina Zachodniego.

W Polsce rósł w siłę stalinizm. Zaczęły się poszukiwania wrogów. Objęło to również Polską Misję Wojskową w Berlinie infiltrowaną przez funkcjonariuszy służb specjalnych PRL. Osadczuk wszedł w konflikt $z$ wpływowym pracownikiem Misji Hubertem Mellerem, co poskutkowało narastaniem wobec niego podejrzeń. Ponadto, kierując się szczera miłością do wolności słowa, wykorzystał w jednej ze swoich publikacji informacje $z$ dokumentu służbowego. Osadczukowi groził są i wobec tego po prostu uciekł z Misji. Stało się to w styczniu 1950 roku. Od tego czasu stał się emigrantem ${ }^{39}$.

${ }^{36}$ Zob. Polska i Ukraina. Rozmowy z Bohdanem Osadczukiem..., s. 92.

37 B. Berdychowska, Bohdan Osadczuk w świetle materiałów archiwalnych IPN, w: Ukraiński polonofil. Pamięci Bohdana Osadczuka..., s. 17.

38 Ibidem, s. 18.

39 Kiedy Armia Czerwona wkroczyła do Polski, rodzice Bohdana Osadczuka wyjechali do niego do Berlina. Wiadomo, że w 1948 r. matka mieszkała u niego. W Berlinie zakończyła swoje życie. Ojciec wkrótce znalazł się w Berlinie Wschodnim, gdzie pracował jako 
Powojenny Berlin Zachodni, zdaniem Basila Kerskiego, był dla Osadczuka:

[...] idealnym miejscem do życia. Mógł tam połączyć tożsamość ukraińskiego emigranta $z$ tożsamościa europejskiego demokraty. Do 1989 roku żył na kosmopolitycznej i demokratycznej wyspie otoczonej czerwonym morzem imperium sowieckiego, w miejscu, gdzie rozstrzygały się losy Europy. Berlin Zachodni był miastem emigrantów, nie tylko tych ze wschodu. Tutaj osiedli niemieccy emigranci polityczni, na przykład burmistrzowie miasta Ernst Reuter i Willy Brandt, politolog Richard Löwenthal czy publicysta Sebastian Haffner. Dzięki nim miasto nabrało nowego, demokratycznego charakteru. Wraz z zachodnimi aliantami i emigrantami z południowej i wschodniej Europy ukształtowali kosmopolityczny klimat powojennego Berlina ${ }^{40}$.

Rzeczywiście historię Berlina Zachodniego można potraktować jako opowieść o ludziach, którzy wybrali to miasto, by bronić demokracji. Wśród tych ludzi znalazł się także Osadczuk.

\section{OD BOHDANA OSADCZUKA DO ALEXANDRA KORABA}

Kogoś innego sytuacja po ucieczce $z$ Polskiej Misji Wojskowej mogłaby zaprowadzić w ślepa uliczkę - tylko nie Osadczuka, którego zawsze ratowały komunikatywność i szerokie kontakty. Zwrócił się do dwóch oficerów CIA - Silbersteina i Mokrego, którzy pomogli mu nawiązać współpracę $z$ niemieckojęzyczna gazetą „Die Neue Zeitung” wydawana za amerykańskie pieniądze do lutego 1955 roku. Pisał o Związku Radzieckim, Polsce, emigracji ukraińskiej, politykach przyjeżdżających do Berlina $z$ Europy Wschodniej. Publikował najpierw pod pseudonimem Hubert Sławek Neuehaus, a następnie Alexander Korab. Ciekawe, że przez dłuższy czas komunistyczne służby specjalne traktowały Osadczuka i Koraba jako dwie różne osoby ${ }^{41}$.

Można tylko podziwiać kolosalną energię i zdolność do pracy naszego bohatera, który pisał do berlińskiego liberalnego dziennika „Der Tagesspiegel”, do monachijskiego dziennika „Münchener Merkur”, a także do dzienników „Stuttgarter Nachrichten” i „Kölner Stadtanzeiger”.

tłumacz w organach NKWD. Niedługo okazało się, że podobno podczas okupacji niemieckiej $\mathrm{w}$ Busku pracował w starostwie, chociaż udziału w przestępstwach nie brał. Ponadto podejrzewano go o szpiegostwo na rzecz USA. W 1947 r. został aresztowany i wywieziony do Polski. Informacje o szpiegostwie się nie potwierdziły. Od 1948 r. współpracował z organami bezpieczeństwa PRL. Ożenił się po raz drugi w $1949 \mathrm{r}$. Spotkał się z synem jesienią $1961 \mathrm{r}$. w Austrii, która odwiedził na zaproszenie kuzynki. Bohdan Osadczuk i jego żona Irena mieli syna Mychajła, który zmarł w wieku 6 lat.

40 B. Kerski, $Z$ Kolomyi $w$ świat..., s. 183.

41 Zob. B. Berdychowska, Bohdan Osadczuk w świetle..., s. 20. 
Z dwoma pismami szwajcarskimi współpracował jako oficjalny korespondent $-z$ „Baseler Nationalzeitung” (jako korespondent berliński) i z "Neue Zürcher Zeitung” (tutaj podjął pracę w 1955 r. i był stałym komentatorem wydarzeń w komunistycznych krajach Europy Wschodniej). Sukcesywnie stał się stałym, cieszącym się autorytetem, publicysta prasy niemieckiej i szwajcarskiej.

Ponadto od 1956 roku Osadczuk był związany $z$ telewizja niemiec$\mathrm{ka}$, brał udział w popularnym cotygodniowym programie politycznym „Internationaler Frühschoppen” (można to przetłumaczyć jako „Międzynarodowe śniadanie"). Ciekawe, że Osadczuk nazwał się przedstawicielem Ukrainy. Po kilku audycjach do Ministerstwa Spraw Zagranicznych przyszła nota dyplomatyczna od ambasadora radzieckiego mówiąca o tym, że nie zna osobnika występującego w imieniu Ukrainy i że wystapienia te szkodzą stosunkom dobrosasiedzkim. Strona radziecka zażądała usunięcia nieznanego pana $z$ audycji. Szef programu Werner Höfer zmartwił się i zaproponował, by Osadczuk wygłosił jakieś oświadczenie, co ten też zrobił. Oto treść oświadczenia zrelacjonowana przez samego Osadczuka:

Jestem gotowy zrezygnować $\mathrm{z}$ reprezentowania Ukrainy pod warunkiem, że do Berlina przyjedzie akredytowany korespondent $z$ Kijowa, przedstawiciel radia lub prasy, i będzie wyrażał się o ustroju sowieckim równie krytycznie jak ja. To jest mój warunek. Jeżeli nie zostanie on spełniony - nie zrezygnuję ze swojego udziału ${ }^{42}$.

Wobec tego kontynuował on udział w programie „Internationaler Frühschoppen" do lat siedemdziesiątych, aż do czasu, gdy dostał niemieckie obywatelstwo, czyli stracił status cudzoziemca. Ponadto od 1956 roku wykładał historię najnowszą Europy Wschodniej na Wolnym Uniwersytecie w Berlinie, gdzie zaprosił go historyk Walter Hofer. Później zaprzyjaźnił się tam z politologiem Richardem Löwenthalem. Ten ostatni zaś blisko współpracował z socjaldemokratą Willym Brandtem, którego Osadczuk wkrótce poznał.

Po wydarzeniach $z$ października 1956 roku w Polsce ${ }^{43}$ Osadczuk szybko został głównym ekspertem do spraw polskich. „Byłem wów-

${ }^{42}$ Polska i Ukraina. Rozmowy z Bohdanem Osadczukiem..., s. 111.

43 Chodzi o wydarzenia zwiazane $z$ fiaskiem planu władz ZSRR, by nie dopuścić do najwyższych stanowisk Władysława Gomułkę (ukaranego w 1951 r. za „odchylenie prawicowo-nacjonalistyczne" kara więzienia, która odbywał do końca 1954 r.). Wbrew zaleceniom Kremla VIII Plenum KC PZPR wybrał nowe Biuro Polityczne, wyrzucajac $z$ niego wszystkich stalinistów. Na I sekretarza KC PZPR wybrano W. Gomułkę, zwolennika „polskiej drogi do socjalizmu”. Szerzej na ten temat zob. V. Golubničij, Rozvitok podì v Pol'ŝi (kviten'-žovten' 1956 r.), „Vpered” (Monachium) 1956, nr 11 (72), s. 5-7; L.W. Gluchowski, E.J. Nalepa, 
czas człowiekiem niezwykle płodnym - wspominał później o tym - pisałem czasami kilka artykułów dziennie"44. Podstawowym źródłem informacji było dla niego radzieckie radio (nauczył się języka rosyjskiego), prasa, spotkania z ludźmi, którzy przyjeżdżali do Berlina i opowiadali o komunistycznej rzeczywistości. „Miałem w owych czasach - pisał później- również inne kontakty i znajomości, gdyż inaczej nie mogłem dawać niemal codziennie komentarzy i ocen na temat wydarzeń w krajach komunistycznych" ${ }^{45}$. Za swojego głównego informatora $\mathrm{w}$ sprawach związanych $z$ Polską uważał warszawskiego pisarza Wiktora Woroszylskiego, $z$ którym przyjaźnił się przez wiele lat ${ }^{46}$.

W owym czasie Osadczuka zaczęła angażować rozgłośnia radiowa RIAS (Rundfunk im amerikanischen Sektor).

\section{OSADCZUK A SŁUŻBY SPECJALNE}

$\mathrm{Na}$ lata pięćdziesiąte przypada nowy wybuch zainteresowania służb specjalnych Osadczukiem. Najpierw chciały go zwerbować służby radzieckie, a potem wywiad PRL. Obie próby skończyły się niepowodzeniem ${ }^{47}$. Po raz kolejny zwiększenie zainteresowania się polskich służb specjalnych Osadczukiem obserwowano w 1962 roku. Teraz wiedziały już, że jest Ukraińcem (chociaż łatwo było to ustalić, śledząc życie emigracji ukraińskiej), miały informacje o jego żonie, miały jego adres, telefon, wiedziały, że ma dwa magnetofony i odbiornik krótkofalowy, domyślały się, że ma informatorów w Polsce. Przy tym cały czas dokonywano perlustracji polskiej korespondencji Osadczuka, analizowano jego publikacje w „Neue Zürcher Zeitung” (sporo tych publikacji przetłumaczono przez służby specjalne PRL na język polski

The Soviet-Polish confrontation of October 1956: the situation in the Polish Internal Security Corps, Woodrow Wilson Internat. Center for Scholars, Washington, D.C. 1997; N.I. Buharin, I.S. Âžborovskaâ, Vladislav Gomulka: na povorotah istorii, „Novaâ i novejšaâ istoriâ” 2011, nr 4, s. 146-168; J. Eisler, Październik 1956. Radzieckie czołgi szły na Warszawe, „Newsweek Historia” 2014, nr 5; İ. Mel'nik, Žovten' 1956-go - poperedžennâ dlâ „komuni”, Zbruč, 21 X 2016, <https://zbruc.eu/node/57669> i in. [dostęp: 23 lipca 2020].

44 Polska i Ukraina. Rozmowy z Bohdanem Osadczukiem..., s. 112.

45 B. Osadczuk, Ukraina, Polska, świat..., s. 264.

46 Wiktor Woroszylski (1927-1996) - polski poeta, prozaik i tłumacz. Były komunista, w latach 70. brał udział w opozycji demokratycznej, objęty zakazem druku. W latach 1978-1981 był wykładowcą Towarzystwa Kursów Naukowych. W grudniu 1981 r. po wprowadzeniu stanu wojennego internowany. Później Osadczuk napisze: „Pomoc Witka była dla mnie niezwykle ważna, gdyż odznaczała się umiarkowaną oceną zachodzących przemian. Dla mnie, przekonanego liberała i oczywiście dla tradycyjnego pisma liberalnego, takie sądy pozbawione zacietrzewienia i resentymentów były bazą dla wystawiania opinii”. B. Osadczuk, Ukraina, polska świat..., s. 265.

47 Zob. B. Berdychowska, Bohdan Osadczuk w świetle..., s. 21. 
do użytku służbowego i te tłumaczenia się zachowały), gromadzono informacje na temat jego ojca. To specyficzne zainteresowanie przetrwało faktycznie do końca istnienia PRL ${ }^{48}$. Bogumiła Berdychowska całkiem sprawiedliwie wskazuje na to, że ze względu na ówczesne realia zimnej wojny i mentalność służb specjalnych charakterystyczne były próby powiązania Osadczuka $z$ wywiadem amerykańskim. To miało wyjaśnić jego wysoką renomę w środowisku dziennikarskim, jego doskonałą orientację w życiu politycznym PRL, a także - do pewnego stopnia - fiasko służb w sprawie werbunku Osadczuka ${ }^{49}$.

W Archiwum Instytutu Pamięci Narodowej w Warszawie zachowało się sporo interesujących dokumentów dotyczących tego praktycznie niezbadanego tematu. Jako jeden $z$ pierwszych w styczniu 1953 roku do Osadczuka dotarł tajny współpracownik oznaczony kryptonimem „B-15”. Według jego słów, Osadczuk „ma bezpośredni kontakt $z$ amerykańskim ośrodkiem wywiadowczym w Berlinie, od którego otrzymuje informacje o uciekinierach, $z$ którymi następnie przeprowadza rozmowy na temat sytuacji w Kraju"50. Zachował się obszerny „ramowy plan operacyjnych przedsięwzięć" w sprawie Osadczuka $z$ dnia 17 października 1962 roku. Plan ten przewidywał m.in. ustalenie osób kontaktowych Osadczuka w Polsce i w Berlinie Zachodnim, zbadanie materialnych warunków jego życia oraz stosunku do niego środowiska dziennikarskiego, zbieranie informacji na temat codziennego rozkładu dnia Osadczuka i jego żony itp. Ponadto plan przewidywał wyjazd do Berlina i próbę skontaktowania się z Osadczukiem tajnych współpracowników o kryptonimach „Bar”, „Krzysztof II” oraz „Ryszard” „Paweł” bardzo wyraźnie określił, dlaczego służby specjalne tak żywo interesowały się jego osoba: „Osadczuk utrzymuje zażyłe stosunki $z$ rozmaitymi politykami niemieckimi, amerykańskimi i posiada wiele informacji, które mają większą wartość dla nas jak dla niego" ${ }^{52}$.

To właśnie za pośrednictwem wspomnianego „Pawła” w 1955 roku w Szwajcarii dokonano próby zwerbowania Osadczuka. Rezultat wydawał się pozytywny, ale niedługo, podczas spotkań w Berlinie Zachodnim stało się jasne, że Osadczuk blefuje i w rzeczywistości nie zamierza udzielać żadnych wartościowych informacji. Mimo to służby specjalne PRL, jak świadcza dokumenty, wciąż nie traciły nadziei na

48 Ibidem, s. 22.

49 Ibidem, s. 23.

50 Archiwum IPN w Warszawie [dalej: AIPN], sygn. BU 003195/711/Diazo, Notatka operacyjna $z$ dn. 20 VII 1953 r., k. 13.

51 AIPN, sygn. BU 01224/512 Jacket, Ramowy plan operacyjnych przedsięwzięć w sprawie Osadczuk Bogdan z dn. 17 X 1962 r., k. 11.

52 Ibidem, Odpis z dn. 20 V 1955 r., k. 75. 
jego pozyskanie. Od 1964 roku Osadczuk w założonej na niego teczce figurował pod kryptonimem „Mann” (w pierwszej sprawie agenturalnego rozpracowania, tuż po jego ucieczce z Polskiej Misji Wojskowej, miał kryptonim „Okulski”). W 1969 r. współpracownicy Polskiej Misji Wojskowej w rozmowach $z$ Osadczukiem próbowali ustalić jego zamiary. Czym to się zakończyło, dobrze opisał inspektor Wydziału VIII Departamentu I MSW PRL Roman Bartczak:

Kontakty te nie wniosły nic istotnego do sprawy. Zachodziło równieź podejrzenie, źe „Mann” podtrzymuje ten kontakt teź w celu zorientowania się co do zamierzeń naszych pracowników. $Z$ tego względu nie widać $\mathrm{w}$ chwili obecnej źadnych realnych moźliwości co do lepszego wykorzystania kontaktu z „Mannem”53.

Niemniej jednak śledzenie Osadczuka kontynuowano, zgromadzone materiały zaś zaczęto wykorzystywać do jego dyskredytacji (pod tym względem najbardziej aktywni byli TW „Tell” i „Atol”. W 1984 roku Osadczukowi podstawiono agenta o kryptonimie „Wiki”. Kontakty te utrzymywano do marca 1987 roku, kiedy to stwierdzono „brak możliwości operacyjnego i informacyjnego rozrzerzenia tej znajomości"54. Następnie samo życie postawiło kropkę w relacjach między Osadczukiem a służbami specjalnymi: powstała niepodległa, antykomunistyczna Polska oraz upadł ZSRR.

\section{MONACHIJSKIE KARTY BIOGRAFII}

Ważne karty biografii Bohdana Osadczuka związane sa z Monachium. To właśnie tutaj nawiązał współpracę $z$ Radiem Swoboda (przed rokiem 1959 - Radio Wolna Europa), gdzie prowadził cotygodniowa audycję „Listy zachodniego liberała”. Założona w okolicznościach zimnej wojny rozgłośnia ta przekazywała swojemu wielonarodowemu audytorium w ZSRR i Europie Wschodniej prawdę o faktach radzieckiej historii i aktualnych wydarzeniach zatajanych przez władze i pomijanych przez oficjalne media. Bardzo istotne były informacje o działalności osób i organizacji występujących przeciwko reżimowi komunistycznemu oraz o represjach przeciwko nim ze strony władz. Rozgłośnia udzielała głosu znajdujacym się w opałach i nonkonformistycznie nastawionym działaczom politycznym, zbiegom, tzw. refuse-

53 AIPN, sygn. BU 02521/59/J, Notatka końcowa ze sprawy krypt. „Mann” z dn. 29 XII 1973 r., k. 17.

54 Ibidem, Notatka końcowa ze sprawy krypt. „Mann” z dn. 10 III 1987 r., k. 56. 
nikom, dysydentom, znanym twórcom ze Związu Radzieckiego i krajów Europy Wschodniej. Jest oczywiste, że takie antykomunistyczne narzędzie, jakim było Radio Swoboda, nie mogło nie zaangażować do współpracy Bohdana Osadczuka, który jako renomowany znawca problematyki Europy Wschodniej chętnie udzielał komentarzy. Nawiązał dobre relacje $z$ kierownikiem sekcji ukraińskiej Mychajłem Dobrianskim-Demkowyczem, a później z jego następcą Bohdanem Nahajłą.

Swoja pracę habilitacyjna, która dawała prawo do zajęcia stanowiska profesora a poświęcona była planom Józefa Piłsudskiego dotyczącym wojny prewencyjnej $z$ Hitlerem, Osadczuk pisał na Wolnym Uniwersytecie w Berlinie. Tutaj w 1966 roku dostał stanowisko profesora. $\mathrm{Na}$ Wolnym Uniwersytecie Ukraińskim w Monachium ${ }^{55}$ pracował jako profesor, a następnie prorektor. Wcześniej, w latach pięćdziesiatych, na tejże uczelni napisał i obronił doktorat na temat polityki narodowościowej w ZSRR od Lenina do Chruszczowa. Spośród najbardziej istotnych publikacji naukowych Osadczuka wymienić należy Rozwój partii komunistycznych $w$ Europie Środkowej i Wschodniej (1962) ${ }^{56}$ oraz Biały orzeł, krzyż $i$ czerwony sztandar. Kronika kryzysów reżimów komunistycznych $w$ Polsce, 1956-1982 (1982) ${ }^{57}$.

W Monachium Osadczuk współpracował i przyjaźnił się z Borysem Łewyckim, który jest mało znany we współczesnej Ukrainie. Dawny nacjonalista, został socjaldemokrata, a następnie liberałem $z$ przekonania. Podobnie jak Osadczuk, dużo i kompetentnie pisał o polityce radzieckiej, o „obozie socjalistycznym”, zdobył autorytet i poważanie nie tylko wśród czytelników, lecz także w środowisku sowietologów ${ }^{58}$.

55 Wolny Uniwersytet Ukraiński (WUU) został założony w dniu 17 I 1921 r. w Wiedniu i jesienia tego samego roku przeniesiony do Pragi, gdzie był finansowany przez struktury rządowe Czechosłowacji. Po wkroczeniu Armii Czerwonej do Pragi zakończył swoje istnienie. Został reaktywowany w Monachium w 1946 r.

56 Zob. A. Korab, Die Entwicklung der kommunistischen Parteien in Ost- und Mitteleuropa. 1. Teil: Polen, Ungarn, Tschechoslowakei, Terrapress, Hamburg 1962.

57 Zob. B. Osadczuk, Weisser Adler, Kreuz und rote Fahne. Chronik der Krisen des kommunistischen Herrschaftssystems in Polen, 1956-1982, Verlag Neue Zürcher Zeitung, Zürich 1982.

58 Borys Łewycki (1915-1984) - dziennikarz, politolog i polityk. W 1939 r. ukończył studia na Uniwersytecie Jana Kazimierza we Lwowie. Dawny zwolennik Stepana Bandery, odszedł od nacjonalistów w 1942 r., od końca wojny mieszkal w Monachium. W 1946 r. był jednym $z$ założycieli Ukraińskiej Partii Rewolucyjno-Demokratycznej. W latach 1949-1956 wraz $z$ Iwanem Majstrenka i Wsewołodem Hołubnyczym współredagował w Monachium organ prasowy lewego skrzydła partii - gazetę „Wpered”. Po 1956 r. zerwał ze środowiskami emigracji ukraińskiej. Poddał krytyce przywódców diaspory ukraińskiej, m.in. za kolaborację z Niemcami podczas II wojny światowej i strategię ostrej retoryki antykomunistycznej. Postulował wspieranie ruchów rewizjonistycznych w krajach Europy Wschodniej i życzliwie wyrażał się o niezależnych wobec ZSRR nurtach komunizmu w rodzaju titoizmu i maoizmu. Począwszy od 1956 r. poświęcił się badaniom sowietologicznym: był m.in. doradcą ds. ZSRR Socjaldemokratycznej Partii Niemiec, współpracownikiem Forschungdienst Osteuropa 
W 1992 roku Osadczuk zaprezentował swoje „atamańskie” cechy, dokonując oceny Wolnego Uniwersytetu Ukraińskiego. W 10. numerze „Kultury” napisał, że z uczelni usunięto demokratów i że uniwersytet został duchowym zapleczem obozu nacjonalistycznego. Ówczesny rektor WUU Petro Goy zaprotestował przeciw tej tezie w liście do redakcji „Kultury”, który Giedroyc opublikował w 3 numerze za rok 1993.

W latach 1984-1987 w Monachium Bohdan Osadczuk spróbował swoich sił nie tylko jako autor i wykładowca, lecz także wydawca, a dokładniej redaktor odpowiedzialny czasopisma „Widnowa”. Miał to być swego rodzaju ukraiński odpowiednik „Kultury”. Nawiasem mówiąc, Jerzy Giedroyc dołączył do kolegium redakcyjnego czasopisma. Osadczuk wspominał:

Idea „Widnowy” wyszła nie ode mnie, lecz od mojego kolegi z Ameryki Jarosława Pełenskiego ${ }^{59}$. On ją rzucił spontanicznie, zaczął pertraktacje ze mna i $z$ innymi, a potem postanowił, że „Widnowa” ma wychodzić w Europie. [...] Nie chcieliśmy się wiąać $z$ żadna grupa polityczna, ale poświęcić się wyłącznie krzewieniu myśli demokratycznej na emigracji. [...] Wydaliśmy kilka numerów poświęconych przede wszystkim stosunkom polsko-ukraińskim, później numer specjalny poświęcony tragedii czarnobylskiej, a potem nagle Pełenski oświadczył, że pora „Widnowę” zlikwidować, bo nie ma funduszy na kontynuowanie pisma. [...] Szkoda, bo to było pismo, które startowało bardzo dobrze i zaczęło się obiecująco rozwijać ${ }^{60}$.

Dużo bardziej udane i korzystniejsze dla relacji polsko-ukraińskich okazało się w zasadzie przypadkowe spotkanie Bohdana Osadczuka $z$ dyrektorem Instytutu Literackiego w Maisons-Laffitte, Jerzym Giedroyciem.

w Düsseldorfie, ekspertem Fundacji im. Friedricha Eberta, publikował w czasopismach „Osteuropa” i „Österreichische Hefte”. Był autorem szeregu prac (po części opublikowanych pod pseudonimem Paul Sikora) tłumaczonych na wiele języków. W ostatnich latach życia wykładał na Wolnym Uniwersytecie Ukraińskim w Monachium. Polowały na niego służby specjalne ZSRR i NRD. Szerzej na ten temat zob. B. Berdychowska, Od nacjonalisty do lewicowca (Przypadek Borysa Łewyckiego), „Zeszyty Historyczne” 2003, nr 145(524), s. 214-230; H. Bubke, Der Einsatz des Stasi- und KGB-Spions Otto Freitag im Müchen der Nachkriegszeit, Verlag Dr. Kovać, Hamburg 2004, s. 114-120.

59 Jarosław Pełenski (ur. 1929) - historyk i politolog, profesor, członek zagraniczny Narodowej Akademii Nauk Ukrainy (1992), członek rzeczywisty Ukraińskiej Wolnej Akademii Nauk (UWAN). Autor prac z zakresu historii Europy Wschodniej późnego średniowiecza i wczesnej nowożytności, stosunków polsko-ukraińskich, ukraińskiej myśli społeczno-politycznej XX w. i studiów politycznych. Od 1987 r. - prezydent Wschodnioeuropejskiego Instytutu Badawczego im. W. Łypynskiego (W.K. Lypynsky East European Research Institute) w Filadelfii (USA). Dyrektor Instytut Badań Wschodnioeuropejskich Narodowej Akademii Nauk Ukrainy (1993-2008; od 2001 r. - Instytut Badań Europejskich NAN Ukrainy). Szerzej na ten temat zob. P. Gaj-Nižnik, Âroslav Pelens'kij. Etapi žittêvogo ì naukovogo šlâhu, „Kiïvs'ka starovina” 2004, nr 1, s. 155-162.

60 Цит. за: Polska i Ukraina. Rozmowy z Bohdanem Osadczukiem..., s. 144-145. 


\section{SPOTKANIE Z GIEDROYCIEM}

Spotkali się w berlińskim hotelu Savoy w czerwcu 1950 roku. To właśnie tam zamieszkali Jerzy Giedroyc i jego najbliższy współpracownik Józef Czapski ${ }^{61}$. Przyjechali na zjazd założycielski Kongresu Wolności Kultury. Obrady odbywały się w pobliżu hotelu. Osadczuk nie był oficjalnie zaproszony do udziału w Kongresie - przyjechał tam jako dziennikarz „Die Neue Zeitung”.

Powstanie Kongresu Wolności Kultury stało się odpowiedzią na różne fora międzynarodowe organizowane przez stalinistów w Berlinie Wschodnim oraz znany Światowy Kongres Intelektualistów w Obronie Pokoju, który odbył się w sierpniu 1948 roku we Wrocławiu. W intencji Moskwy celem tego kongresu było pokazanie, że większość intelektualistów w Europie popiera komunizm.

Na Kongresie w Berlinie Zachodnim dominowali antykomuniści, którzy utworzyli alternatywę dla lewicujących intelektualistów Zachodu mających prosowieckie orientacje i serwujących światu złudzenia na temat Związku Radzieckiego. Berliński Kongres także apelował do zwolenników pokoju, $z$ jednym tylko zastrzeżeniem: był skierowany do przekonanych antykomunistów, którzy wiedzieli i rozumieli, co w rzeczywistości dzieje się w stalinowskim ZSRR. Pomysłodawcą Kongresu był publicysta, założyciel liberalnego miesięcznika „Der Monat”, Melvin Lasky, dawny trockista $z$ Nowego Jorku. Inicjatorzy Kongresu należeli zatem do ludzi, których zachodni alianci po podziale Niemiec i Berlina darzyli zaufaniem ${ }^{62}$.

Tym bardziej wrogi był stosunek do uczestników Kongresu ze strony stalinistów. „Na Kongresie - wspominał później Giedroyc - panowała atmosfera strachu; wielu uczestników bało się porwania przez NKWD”63. Niemniej jednak Kongres, podczas którego żywe przemówienie (rozpoczęte w języku niemieckim) wygłosił Józef Czapski, odbył się. Było to jedyne przemówienie, w którym została poruszona m.in. kwestia ukraińska. Właśnie dzięki temu spotkali się i poznali Giedroyc i Osadczuk ${ }^{64}$.

61 Józef Czapski (1896-1993) - artysta malarz, pisarz, krytyk literacki, więzień Gułagu, autor wspomnień o łagrach Wspomnienia starobielskie (1944), Na nieludzkiej ziemi (1949). Jeden z najbliższych współpracowników J. Giedroycia, współzałożyciel i członek zespołu redakcyjnego „Kultury”.

62 Szerzej na ten temat zob. P. Grèmion, Konspiracja wolności. Kongres Wolności Kultury (1950-1975), Wydawnictwo Naukowe PWN, Warszawa 2004.

63 J. Gedroyc, Autobiografia na cztery ręce, opr. i posł. opatrzył K. Pomian, wyd. 4, Towarzystwo Opieki nad Archiwum Instytutu Literackiego w Paryżu, Warszawa 2006, s. 188.

64 „Dla obydwu przybyszów z Zachodu byłem nieznanym, trochę egzotycznym ptakiem. Nic o mnie nie wiedzieli i zdaje się, że $z$ trudem przyjmowali do wiadomości moje opowieści 


\section{Ten ostatni wspominał:}

Pierwsza rozmowa była niepozbawiona elementów dystansu i nieufności. Ale jeśli chodzi o piszącego, była wydarzeniem przełomowym w stosunku do poprzednich poszukiwań. Stało się jasne, że nareszcie mam do czynienia ze środowiskiem świadomym swych celów, niezależnym w myśleniu i tworzeniu nowych treści [...]. I tak zaczęła się nasza współpraca $[\ldots]^{65}$.

Nawiazanie dobrych relacji z Ukraina było dla Giedroycia, podobnie jak niepodległość Polski, sprawą jego życia. Jeszcze w latach trzydziestych, w warunkach polsko-ukraińskiej konfrontacji, Giedroyc jako redaktor opiniotwórczych czasopism młodych konserwatystów („Bunt Młodych”, następnie „Polityka”) i jako urzędnik państwowy szukał dróg porozumienia. Był przekonany, że aby rozpocząć dialog, należy przede wszystkim dojrzeć i uznać w Ukraińcach partnerów. Później, znalazłszy się wraz z Armia gen. Władysława Andersa na Bliskim Wschodzie, Giedroyc wydał dla żołnierzy pochodzenia ukraińskiego modlitewnik w ich języku ojczystym.

Warto przypomnieć, że na przełomie lat czterdziestych i pięćdziesiatych XX wieku, po tragicznej bratobójczej walce między Polakami a Ukraińcami, było niezbyt wielu chętnych do prowadzenia dialogu - właśnie dialogu, a nie rozbudowywania listy wzajemnych oskarżeń. $Z$ tego też powodu inicjatywa Giedroycia dotyczaca wypracowania koncepcji przyszłych stosunków polsko-ukraińskich ziściła się nie od razu. Początkowo, w 1948 roku, Giedroyc zaproponował opracowanie takiej koncepcji działaczom, którzy zaskarbili sobie szacunek wśród Ukraińców - np. Jerzemu Stempowskiemu ${ }^{66}$, synowi Stanisława Stempowskiego, ministra w rządzie Symona Petlury; autorowi epopei z życia Huculszczyzny Na wysokiej połoninie Stanisławowi Vincenzowi ${ }^{67}$;

o losach człowieka rzuconego $z$ dalekiej Kołomyi do Polski centralnej, a potem do Berlina. Ja natomiast o nich coś niecoś wiedziałem. O Czapskim $z$ opowieści młodego Łubieńskiego z Kazimierzy Wielkiej, a o Giedroyciu najpierw ze sporadycznej lektury "Polityki» wypożyczanej mi przez gazeciarza Lopka w Pińczowie, a potem $z$ ust byłego posła na Sejm $z$ Wołynia, Stepana Skrypnyka, kuzyna atamana Petlury i przyjaciela wojewody Józewskiego - podczas rozmów w 1940 roku w Chełmie Lubelskim, a trochę później od Henadiego Kotorowycza, dziennikarza ukraińskiego, który był sprawozdawca parlamentarnym "Polityki». [...] Odczułem, że znalazłem wreszcie to, czego szukałem i o czym marzyłem: drogę do dialogu i partnerstwa”. B. Osadczuk, Rola Jerzego Giedroycia w stosunkach polsko-ukrainskich, w: Jerzy Giedroyc-Redaktor, Polityk, Człowiek, red. K. Pomian, Lublin 2001, s. 159.

65 B. Osadczuk, Ukraina, Polska, świat..., s. 128.

66 Jerzy Stempowski (1893-1969) krytyk teatralny, tłumacz, jeden z najwybitniejszych polskich eseistów. Od 1940 r. mieszkał w Szwajcarii. Publikował pod pseudonimem Pawel Hostowiec. Od niego Bohdan Osadczuk później przejął rolę pośrednika między „Kulturą” a emigracją ukraińską.

67 Stanisław Vincenz (1888-1971) - pisarz, filozof, eseista, tłumacz, współpracował $z$ „Kultura”. 
wybitnemu myślicielowi politycznemu Piotrowi Dunin-Borkowskie$\mathrm{mu}^{68}$. Przedwczesna śmierć tego ostatniego uniemożliwiła realizację tej inicjatywy, ale Giedroyc wkrótce znalazł inny sposób.

Zainicjował debatę publiczną wokół najbardziej bolesnego wówczas problemu - kwestii uznania nowych granic Polski. Wywołało to przewidywaną falę oburzenia wśród prenumeratorów „Kultury” i wznieciło ostra dyskusję. Giedroyc nie zamierzał jednak się wycofywać - kontynuował debatę, jednocześnie ukazując na łamach pisma rożne wydarzenia $z$ polsko-ukraińskiej historii i współczesności. Pierwszym tekstem, który uczynił relacje polsko-ukraińskie przedmiotem żywej dyskusji, był opublikowany w 2 numerze „Kultury” za rok 1952 artykuł poety i tłumacza Józefa Łobodowskiego ${ }^{69}$ Przeciw upiorom przeszłości. Warto podkreślić, że od samego początku istnienia pisma publikowano w nim teksty literatury ukraińskiej w przekładach Łobodowskiego, a także jego artykuły o tej literaturze - do 1996 roku ukazało się łącznie 130 takich publikacji ${ }^{70}$.

W „Kulturze” pojawił się nowy dział „Kronika ukraińska”, którego stałym autorem został Bohdan Osadczuk. Swój udział w tej rubryce zainaugurował w czerwcowym numerze czasopisma za rok 1952 publikacja Kronika polsko-ukrainska pod pseudonimem $\mathrm{BEO}^{71}$. Osadczuk stale publikował w „Kulturze” aż do czasu zamknięcia czasopisma, czyli do 2000 roku włącznie. Były to głównie teksty o życiu emigracji ukraińskiej, stosunkach polsko-ukraińskich oraz sytuacji politycznej w krajach bloku wschodniego i w Niemczech. W 637 numerach „Kultury” ukazało się około 160 artykułów Osadczuka, poza tym zachowało się około 900 listów wymienionych między Osadczukiem a Giedroyciem ${ }^{72}$.

Ten ostatni później napisze:

Bohdan Osadczuk był i jest nie tylko dokładnym informatorem o stosunkach polsko-ukraińskich, ale przede wszystkim ułatwił „Kulturze” nawiązanie kontaktów z czołowymi działaczami ukraińskimi. Rozpoczynając naszą działalność,

68 Piotr Dunin-Borkowski (1890-1949) - polityk, działacz państwowy, publicysta. Był zwiąany z czasopismami „Bunt Młodych” i „Polityka” redagowanymi przez J. Giedroycia. Był orędownikiem współpracy polsko-ukraińskiej wobec zagrożenia ze strony ZSRR.

69 Józef Łobodowski (1909-1988) - poeta, publicysta, prozaik, tłumacz. W latach 1914-1922 przebywał w Rosji i Gruzji, następnie zamieszkał w Polsce. Od 1939 r. na emigracji. Od 1941 r. mieszkał w Hiszpanii, był współzałożycielem oraz w latach 1945-1975 redaktorem polskiej sekcji Radia Madryt. Jeden z kluczowych ekspertów ds. ukraińskich wśród współpracowników „Kultury”.

70 Zob. L. Šaruga, „Kul'tura” i ukrainskij vopros, „Novaâ Pol'ša” 2006, nr 2, s. 19.

71 BEO, Kronika polsko-ukrainska, „Kultura” 1952, nr 5, s. 125-132.

72 Zob. W. Sikora, Pożegnanie Bohdana Osadczuka, w: Ukraiński Polonofil. Pamięci Bohdana Osadczuka..., s. 74. 
nie byliśmy zupełnie zorientowani, jak wygląda emigracja ukraińska na Zachodzie, i tutaj Osadczuk był przede wszystkim bardzo cennym kontaktmenem ${ }^{73}$.

\section{Z kolei Bohdan Osadczuk w artykule Rola Jerzego Giedroycia} $w$ stosunkach polsko-ukrainskich pisał:

Niekiedy męczyłem Jerzego, aby mi wyjaśnił, jak i dlaczego odkrył sprawę ukraińską. [...] Zaczęło się to od uczęszczania na wykłady Myrona Korduby ${ }^{74}$ o historii Ukrainy. Giedroyc był już po studiach prawa, więc chodzenie na lekcje i seminaria profesora Korduby, specjalisty od zagadnień etnicznych i terytorialno-granicznych, było prywatnym luksusem młodego polityka i poczatkujacego redaktora. Wykłady warszawskiego historyka ukraińskiego odegrały w politycznej i wydawniczej karierze Jerzego Giedroycia ogromna rolę. Sprawa ukraińska stała się dla niego centralnym zagadnieniem na całe życie ${ }^{75}$.

Mimo że centralnym zagadnieniem w całym życiu Giedroycia była sprawa polska, opinia Osadczuka jest jednak sprawiedliwa. Giedroyc bowiem w sposób jednoznaczny uzależniał rozstrzygnięcie sprawy polskiej od rozwiązania kwestii ukraińskiej. Bogumiła Berdychowska trafnie wskazuje kluczowe elementy ukraińskiej strategii Giedroycia, do których należały: dyskusja wokół kwestii granic; refleksja nad dziedzictwem historycznym i krytyczna analiza polsko-ukraińskiej przeszłości; systematyczna obserwacja przemian zachodzacych na Ukrainie oraz próby wpływania na zachodzące w niej procesy; wysiłki na rzecz „umiędzynarodowienia” sprawy ukraińskiej; możliwie wszechstronna prezentacja kultury ukraińskiej ${ }^{76}$.

Kwestia ukraińska w działalności „Kultury” nie była czymś odizolowanym - wpisywała się w projekt nakreślony w zasadniczym artykule Juliusza Mieroszewskiego ${ }^{77}$ Rosyjski „kompleks polski” $i$ obszar $U L B$ (1974). Pisał w nim m.in.:

W Europie Wschodniej - jeżeli na tych ziemiach ma kiedyś ustalić się nie tylko pokój lecz wolność - nie ma miejsca na żaden imperializm - ani rosyjski ani polski. Nie możemy gardłować, że Rosjanie winni oddać Ukraińcom Kijów i równocześnie głosić, że Lwów musi wrócić do Polski ${ }^{78}$.

${ }^{73}$ J. Giedroyc, Słowo wstępne, w: B. Osadczuk, Ukraina, Polska, świat..., s. 5.

74 Myron Korduba (1876-1947) - historyk, publicysta, tłumacz. Od 1929 r. wykładał na Uniwersytecie Warszawskim do czasu jego zamknięcia przez Niemców, w latach 1944-1947 wykładał na Uniwersytecie Lwowskim.

75 B. Osadczuk, Rola Jerzego Giedroycia..., s. 163.

76 Zob. B. Berdychowska, Giedroyc i Ukraincy, w: J. Giedroyc, Emigracja ukraińska, Listy $1950-1982 \ldots$, s. 26.

77 Juliusz Mieroszewski (1906-1976) - dziennikarz, publicysta, obserwator polityczny. Podczas II wojny światowej wyjechał z Polski, pracował jako publicysta dla polskiego rzadu na emigracji, mieszkał w Londynie. W latach 1950-1972 - redaktor Kroniki angielskiej w czasopiśmie „Kultura”.

78 J. Mieroszewski, Rosyjski „kompleks polski” i obszar ULB, „Kultura” 1974, nr 89, s. 7. 


\section{I następnie:}

Jeżeli dla uproszczenia obszar obejmujacy Ukrainę, Litwę i Białoruś określimy literami ULB - to należy stwierdzić, że w przeszłości - a poniekąd i dziś obszar ULB był czymś więcej niż „kościa niezgody”, pomiędzy Polska a Rosja. Obszar ULB determinował formę stosunków polsko-rosyjskich, skazując nas albo na imperializm, albo na satelictwo ${ }^{79}$.

Do likwidacji tego smutnego dylematu może doprowadzić jedynie konsekwentna praca na rzecz zbudowania suwerenności obszaru ULB - taka była kluczowa teza Mieroszewskiego i Giedroycia.

Jednym $z$ podstawowych problemów zwiazanych $z$ kwestia ukraińska stał się postulat rezygnacji $z$ mitologii tzw. Kresów Wschodnich. W liście do Leszka Szarugi napisanym w połowie lat dziewięćdziesiątych Jerzy Giedroyc proponował, by zrezygnować z pojęć „Kresy” i „kresowy" jako obraźliwych dla Ukraińców i kojarzących im się z imperialna historia Polski oraz zastapić je pojecciami „pogranicze”, „pograniczny”80. Giedroyc nigdy nie idealizował relacji polsko-ukraińskich. Bez iluzji patrzył na nie również Osadczuk. Uważał, że są to:

[...] dwie nacje, których rozwój historyczny był bardzo odmienny. Pokrewieństwa istniały tylko na początku naszych dziejów za Polski Piastów i Rusi Kijowskiej. Potem drogi się rozchodza i prowadzą do zupełnie odmiennych procesów. Polska piastowska rośnie w siłę, a Ruś-Ukraina pogrą̇a się w niemocy. Najdotkliwszym ciosem zadanym Rusinom-Ukraińcom było nieuznanie tej części „imperium” jagiellońskiego za autonomiczny człon, równy Koronie i Litwie. Kolejnymi tragicznymi rozdziałami było zlekceważenie prawosławia i niezrozumienie roli Kościoła greckokatolickiego. W rezultacie ekspansji Kościoła rzymskokatolickiego, w danym wypadku identycznej $z$ dominacja polską, Ukraina utraciła wielką część swojej arystokracji. Druga połknie później carska Rosja na lewobrzeżnej Ukrainie [...]"81.

\section{Następstwem takiego stanu rzeczy zdaniem Osadczuka był:}

[...] element wyższości w postawie Polaków, stosunek „panów” wobec „chamów”, który utwierdził się w okresie rozbiorów we włościach polskich ziemian na ziemiach ukraińskich, głównie na prawobrzeżnej Ukrainie, a pogłębił w wyniku kolaboracji polskiej szlachty z władza rosyjską w zamian za tolerowanie przywilejów własnościowych. Wcześniejsze wojny kozackie nie przyniosły zmiany na lepsze, utwierdziły raczej stereotyp Ukraińca-warchoła, a $z$ czasem „mordercy-rezuna”. Operowanie tego rodzaju prototypami wzmoże się szczególnie w okresie PRL, kiedy po zużyciu wrogiego stereotypu Niemca i z uwagi na powstanie państwa „dobrych Niemców” - Niemieckiej Republiki Demokratycznej,

\footnotetext{
79 Ibidem.

80 Zob. L. Šaruga, „Kul'tura” i ukrainskij..., s. 20.

81 Cyt. za: Polska i Ukraina. Rozmowy z Bohdanem Osadczukiem..., s. 41.
} 
należało znaleźć inny obiekt dla „gniewu ludu”, odwracający uwage od zbrodni stalinowskich. Utrwalono w ten sposób obraz ukraińskiego wroga $[\ldots]^{82}$.

Nieostatnia rolę $\mathrm{w}$ relacjach polsko-ukraińskich odgrywały negatywne stereotypy obu narodów w stosunku do siebie. Osadczuk próbował je burzyć. Ciekawe jest, że wraz z Jerzym Stempowskim, Stanisławem Vincenzem i Józefem Łobodowskim stworzył on swego rodzaju lobby ukraińskie w „Kulturze”, w którym był jedynym Ukraińcem $z$ pochodzenia. Poza tym dużo zrobił $\mathrm{w}$ zakresie angażowania do współpracy $z$ „Kulturą" ukraińskich autorów $z$ kręgu młodszej emigracji ukraińskiej, próbował nawiązać współpracę $z$ przedstawicielami emigracji ukraińskiej zza Zbrucza. Mowa o tzw. wschodniakach z Ukraińskiej Partii Rewolucyjno-Demokratycznej (UPRD) z pisarzem i działaczem społecznym Iwanem Bahrianym ${ }^{83}$ na czele, $z$ którymi Osadczuk się zbliżył i przez pewien należał do wspomnianej partii.

To akurat nie było proste. Nieliczni przedstawiciele tego środowiska rozumieli wage i znaczenie umocnienia relacji z Polakami. Nad kolegami i przyjaciółmi Osadczuka ciążł propagandowy stereotyp antyukraińskiej roli „białopolaków”. Osadczuk walczył z tymi poglądami na łamach gazety „Ukrajinśki Wisti” będącej podówczas jedyną demokratyczna trybuna dla ukraińskiej emigracji politycznej. Od samego początku głosił solidarność z ideami Symona Petlury (co odpowiadało przekonaniom Giedrycia). Osadczuk stawiał nie na III wojnę światowa, jak np. ówcześni nacjonaliści z obozu banderowców (nawiasem mówiąc, robili to również radykalnie nastawieni przedstawiciele polskiej emigracji), tylko na sukcesywne pokojowe zmiany, czyli na bliski ideom Giedroycia i Mieroszewskiego ewolucjonizm.

Poza tym wspomniane już związki Osadczuka $z$ prasa niemiecka i szwajcarska przyczyniały się do promocji idei „Kultury” na jej łamach. Inną ważną sferą współpracy z Giedroyciem stało się poszukiwanie i pozyskiwanie nowych współpracowników $z$ grona znanych Osadczukowi intelektualistów i publicystów ukraińskich.

Dzięki pośrednictwu Osadczuka Giedroyc nawiązał kontakty z Borysem Łewyckim, Iwanem Łysiakiem-Rudnyckim, Lubomyrem

82 Ibidem, s. 42.

83 Iwan Bahriany (1906-1963) - pisarz i działacz polityczny, od 1945 r. przebywał na emigracji w Niemczech, gdzie w 1948 r. założył Ukraińską Partię Rewolucyjno-Demokratyczna (UPRD) i redagował gazetę „Ukrajinśki Wisti”. Był pretendentem do Nagrody Nobla w dziedzinie literatury i miał szanse, by ją dostać, ponieważ napisał dwie powieści o Gułagu (Ogród Getsemański i Łowcy tygrysów) na 20 lat przed napisaniem Archipełagu GUŁag przez Aleksandra Sołżenicyna, ale nagła śmierć Bahrianego przeszkodziła jego oficjalnej nominacji do tej nagrody. 
Ortynskim ${ }^{84}$. Aktywnym korespondentem „Kultury” został Iwan Koszeliwe $c^{85}$, początkowo redaktor pisma „Ukrajinśka Literaturna Hazeta”, a potem miesięcznika „Suczasnist”. Ponadto wśród publicystów i autorów „Kultury” można wymienić tak znanych przedstawicieli emigracji ukraińskiej jak Łeonid Mosendz ${ }^{86}$, Jewhen Małaniuk ${ }^{87}$, Jurij Ławrinenko ${ }^{88}$, prof. Mykoła Hłobenko - historyk literatury i sekretarz Encyklopedii ukrainoznawstwa ${ }^{89}$.

Później Osadczuk napisze:

Podstawową sprawą w mojej współpracy z Jerzym Giedroyciem było wytyczanie drogi do pokonywania starych konfliktów i szukania rozwiązań na przyszłość. Giedroyc był w tym kontekście postacią kluczową, dominująca. Posiadał talent i upór wizjonerski. [...] Miał jak nikt historyczną perspektywę, w którą wierzył bez wahań. [...] Robił to bez fanatyzmu jak coś zupełnie normalnego. Pamiętam, że nieraz w naszych licznych i długich rozmowach w Maisons-Laffitte wyrażałem czasem watpliwości lub zastrzeżenia. Jerzy Giedroyc wysłuchiwał wszystkiego cierpliwie, a potem mnie korygował, nigdy się nie unosząc ${ }^{90}$.

Tandem dwóch nieprzeciętnych emigrantów - Giedroycia i Osadczuka działał $z$ powodzeniem. Oderwani od swoich krajów, pozbawieni realnej możliwości sprawdzenia, jakie panuja opinie i nastroje w spo-

84 Lubomyr Ortynsky (1919-1961) - publicysta, działacz OUN, współzałożyciel Związku Ukraińskich Kombatantów, redaktor czasopisma „Wisti”, współpracownik Radia Swoboda.

85 Iwan Koszeliweć (1907-1999) - badacz literatury, krytyk, publicysta, tłumacz, redaktor naczelny czasopisma „Suczastnist” (1961-66, 1976-77, 1983-84). Na emigracji od 1944 r., mieszkał w Austrii, Niemczech. Najbardziej solidnym projektem zrealizowanym przez Koszeliwcia na zamówienie Instytutu Literackiego była antologia Ukraina 1956-1968 wydana w 1969 r. w języku polskim.

86 Łeonid Mosendz (1897-1948) - poeta, prozaik, eseista, pisał pod pseudonimem Łeonid Korzon. Po porażce UNR w 1920 r. wyemigrował do Polski, następnie mieszkał w Czechach, Słowacji, Austrii, Szwajcarii. Był pierwszym autorem ukraińskim, którego artykuł pojawił się na łamach „Kultury” w 1948 r.

87 Jewhen Małaniuk (1897-1968) - poeta, publicysta, historiozof. Po porażce UNR w 1920 r. wyemigrował do Polski, mieszkał w Czechach, Niemczech, od 1949 r. w USA. Jego pierwsza publikacja w „Kulturze” ukazała się w 1948 r. pod pseudonimem Julian Kardosz. Artykuł poświęcony był życiu kulturalnemu emigracji ukraińskiej. Szczególnie bliskie relacje łaczyły Małaniuka ze Stanisławem Stempowskim. J. Giedroyc pragną, aby Małaniuk częściej publikował w „Kulturze” (zob. J. Giedroyc, J. Małaniuk, Listy 1948-1963, oprac., wstęp, przyp. H. Dubyk, Instytut Dokumentacji i Studiów nad Literaturą Polska, Warszawa 2014).

88 Jurij Ławrinenko (1905-1987) - krytyk, historyk literatury, przebywał na emigracji od 1944 r., najpierw w Austrii, następnie w Niemczech, w 1950 r. wyjechał do USA. Publikował pod pseudonimem Jurij Dywnycz. To właśnie jemu J. Giedroyc zaproponował stworzenie antologii literatury ukraińskiej Rozstrzelane odrodzenie opublikowanej przez Instytut Literacki w języku ukraińskim w 1959 r.

89 Mykoła Hłobenko (1902-1957) - badacz literatury, pedagog. W 1943 r. udał się na emigrację, w Monachium był redaktorem tygodnika politycznego „Ukrajinśka Trybuna” (ukazywał się w latach 1947-1949). Po raz pierwszy wystąpił na łamach „Kultury” w 1950 r., publikując pod pseudonimem M. Słobożanin swoje wspomnienia o ukraińskim życiu literackim końca lat dwudziestych dotyczace m.in. procesu tzw. Związku Wyzwolenia Ukrainy.

90 B. Osadczuk, Rola Jerzego Giedroycia..., s. 162. 
łeczeństwach zdanych na łaskę wrogiej i kłamliwej propagandy, działali wbrew nastrojom dominujacym w środowiskach emigranckich. Nastroje te były podsycane przez zadawnione konflikty między Polakami a Ukraińcami (zaostrzone podczas II wojny światowej i podczas deportacji w ramach Akcji „Wisła” w 1947 roku) ${ }^{91}$.

Osadczuk i Giedroyc rozpoczęli dialog, który pomógł pokonać dawne uprzedzenia i wzajemne oskarżenia, a wydawane w języku polskim czasopismo „Kultura” przez długi czas było jedyna platforma do prowadzenia tego rodzaju dyskusji (Ukraińcy nie mieli tak niezależnego odpowiednika). Osadczuk był przekonany że bez Giedroycia:

[...] polsko-ukraińskie pogranicze mogłoby dziś być polsko-ukraińskim Kosowem - wzajemna mordownią. Natomiast po długim paśmie konfliktów i wojen, krótkich okresach przyjaźni, mamy już od wielu lat system oparty na wzajemnym porozumieniu i obopólnej potrzebie współpracy, a nawet przyjaźni, przypominajacy w zarysach realizację planów i umów Józefa Piłsudskiego z Semenem Petlura. Bez Jerzego Giedroycia, jego wizji i praktycznej działalności, nie mielibyśmy tego. Jestem dumny i szczęśliwy, że mogłem wraz z nim w tym dziele uczestniczyćc ${ }^{92}$.

Do tych słów można $z$ całkowita pewnościa dodać, że również bez Bohdana Osadczuka nie mogło nastąpić ocieplenie stosunków polsko-ukraińskich, niemożliwe byłoby wzajemne rozumienie dwóch krajów mające zasadnicze znaczenie także w dzisiejszym krajobrazie geopolitycznym Europy.

\section{PO GIEDROYCIU}

Jerzy Giedroyc odszedł w 2000 roku, czyli już po transformacji systemowej w Polsce i ogłoszeniu niepodległości Ukrainy. Nigdy nie przyjechał do kraju po obaleniu komunizmu, mimo że niejednokrotnie go zapraszano. Wraz z Redaktorem odszedł do historii miesięcznik „Kultura”, gdyż Giedroyc zapowiedział zamknięcie pisma po jego śmierci.

91 Akcja „Wisła” (pierwotny kryptonim „Wschód”) została rozpoczęta w kwietniu 1947 r. przez komunistyczne władze PRL. W jej wyniku ponad 150 tys. obywateli PRL narodowości ukraińskiej przesiedlono $z$ terenów południowo-wschodnich Polski na obszary zachodnie i północno-zachodnie, w tym tzw. Ziemie Odzyskane przyłączone do Polski po klęsce Niemiec nazistowskich. W akcji brało udział ponad 20 tys. żołnierzy Wojska Polskiego, nie licząc lokalnej milicji obywatelskiej, funkcjonariuszy SB i pograniczników. Ukraińców osiedlano, zachowujac pewne proporcje, w gorszych warunkach w porównaniu z Polakami. Formalnie Akcja „Wisła” została zakończona w lipcu 1947 r., jednak przesiedlenia faktycznie trwały do października tegoż roku. Szerzej na ten temat zob. np. Pol'ŝa ta Ukraïna u tridcâtih-sorokovih rokah XX stolittâ. Nevìdomì dokumenti $z$ arhìvìv special'nih služb, t. 5: Akcìâ „Visla” 1947, İnstitut nacional'noï pam`âtì, Varšava - Kiïv 2006.

92 B. Osadczuk, Rola Jerzego Giedroycia..., s. 167. 
Bohdan Osadczuk zaczał odwiedzać Polskę w 1989 roku, a do Kijowa po raz pierwszy przyjechał w 1990 roku, jeszcze przed wystapieniem Ukrainy ze Związku Radzieckiego. Potem niejednokrotnie bywał we Lwowie, Kołomyi, Charkowie, Czerniowcach, Doniecku. Odbywał spotkania, brał udział w forach naukowych i nie tylko, dyskutowal, spotykał się $z$ prezydentami Łeonidem Krawczukiem i Łeonidem Kuczma, dawał rekomendacje, dzielił się doświadczeniem. Procesy demokratyzacji otworzyły mu drzwi do Polski. Spotykał się z prezydentem Lechem Wałęsa i współpracował $z$ prezydentem Aleksandrem Kwaśniewskim. Aktywnie publikował w polskich i ukraińskich periodykach, bez udawanej dyplomatyczności reagując na wszystkie osiągnięcia i niepowodzenia w stosunkach polsko-ukraińckich już w nowych warunkach, pojawiał się w radiu i telewizji. W Kijowie jego teksty po raz pierwszy od wielu lat zaczęto redagować, co stało się powodem jego rezygnacji ze współpracy $z$ dziennikiem „Hołos Ukrajiny” będącym organem Rady Najwyższej (redaktorem naczelnym był wówczas Serhij Prawdenko), nadal jednak publikował w innych pismach.

W dniu 19 października 2011 roku Bohdan Osadczuk zmarł w domu swojej opiekunki Agaty Freitag w Czechówce koło Myślenic w województwie małopolskim. Ciężko jest dokładnie zrozumieć, jak znalazł się w tej wsi. Wspomnianą opiekunkę zaprezentowano w publikacji lokalnego dziennika tuż po pogrzebie Osadczuka jako „psychoterapeutę w jednej z berlińskich klinik”, jako „asystentkę profesora” i jego „sekretarkę"93. Opowiedziała o tym, że do państwa Osadczuków trafiła dzięki znajomości $z$ panią Irena i na jej zaproszenie. Wkrótce po tym, w 2008 roku małżonka profesora zmarła i została pochowana w Augsburgu w Bawarii. Latem 2009 roku Agata Freitag po raz pierwszy przywiozła Osadczuka do domu swoich rodziców w Czechówce, potem też spędził $z$ nimi Święta Bożego Narodzenia. Według słów opiekunki, w sierpniu 2011 roku, po tygodniowym pobycie w jednym $z$ berlińskich szpitali, Osadczuk zaczął kategorycznie domagać się, by Freitag zabrała go do Polski, co też zostało zrobione ${ }^{94}$.

Niezwykle interesujacca jest wiadomość o tym, że opiekunka wraz $z$ redaktorem Witoldem Ślusarskim opracowywała wspomnienia Osadczuka. „Z autoryzacja wspomnień uporaliśmy się 5 dni przed jego śmiercią" - oznajmiła Agata Freitag ${ }^{95}$. Wspomnienia te (o ile istnieja) nie zostały jak dotąd opublikowane.

93 Aga, zabierz mnie do Polski, chce nia pooddychać! Prof. Bohdan Osadczuk zmart w Czechówce, „Dziennik Polski. Myślenicki Tygodnik”, 29 X 2011.

94 Ibidem.

95 Ibidem. 
W 2017 roku udałem się z Krakowa do Czechówki. Tam znalazłem dom pod numerem 132 przy ul. Szkolnej. To właśnie tutaj spędził swoje ostatnie dni Bohdan Osadczuk. Pani Krystyna Firek, matka Agaty Freitag, zgodziła się porozmawiać ze mną, podzielić się wspomnieniami o swoim lokatorze, zaprosiła do domu. Pokazała mi kilka albumów fotograficznych należących do Osadczuka oraz jego archiwum spakowane w dość dużą liczbę pudeł kartonowych, Na moje pytanie, co zamierza zrobić $z$ archiwum, odpowiedziała, że chciałaby sprzedać komuś, kto tym się interesuje.

Pogrzeb Bohdana Osadczuka odbył się 25 października 2011 roku w parafii pw. Wszystkich Świętych w Zakliczynie. Odczytano list Prezydenta RP Bronisława Komorowskiego, który nazwał Osadczuka

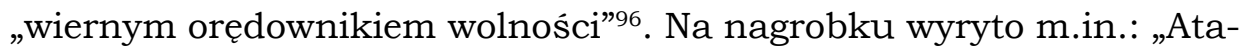
man pojednania polsko-ukraińskiego. Orędownik pokoju na świecie”. „Gazeta Wyborcza” napisała: „Nie sposób wyobrazić sobie bez niego polsko-ukraińskiego pojednania. Budował je, gdy nie było wolnej Polski ani wolnej Ukrainy"97.

W 1983 roku Osadczuk dostał ustanowiona przez „Kulturę” paryską Nagrodę Przyjaźni i Współpracy, w 2001 roku Prezydent RP uhonorował go najwyższym odznaczeniem państwowym - Orderem Orła Białego w uznaniu znamienitych zasług dla Rzeczypospolitej Polskiej. W 2001 roku Prezydent Ukrainy uhonorował Osadczuka Orderem Jarosława Mądrego V stopnia, wtedy też przyznano mu obywatelstwo honorowe miasta Kołomyi. W 2005 roku przyznano mu doktorat honoris causa Donieckiego Uniwersytetu Narodowego, a w 2006 roku Narodowego Uniwersytetu Akademia Kijowsko-Mohylańska.

Dostał również inne nagrody i tytuły, ale chyba najbardziej trafnie zdefiniowaną i przez to najważniejszą, odzwierciedlającą dogłębnie istotę dorobku Osadczuka nagroda było przyznanie mu w Polsce tytułu Człowiek Pogranicza za lata 2005-2006. Nagrodę tę wręczono mu na początku listopada 2006 roku w Sejnach, w północno-wschodniej Polsce, gdzie ma swoją siedzibę Ośrodek „Pogranicze - sztuk, kultur, narodów" i Fundacja Pogranicze. Założyciel Ośrodka i Fundacji eseista Krzysztof Czyżewski wyjaśniał, że zwrot „człowiek pogranicza” odnosi się do:

[...] osoby tolerancyjnej, często o splątanych korzeniach rodzinnych, którą cechowały empatia, krytyczny patriotyzm, odporność na narodowe fobie, bie-

96 Cyt. za: Ukraiński polonofil. Pamięci Bohdana Osadczuka..., s. 13.

97 M. Wojciechowski, Zmark prof. Bohdan Osadczuk. Ukrainski Polak, polski Ukrainiec, „Gazeta Wyborcza”, 20 X 2011. 
głość w językach, ciekawość innego i, połączona $z$ otwartością na świat, miłość do swojej małej ojczyzny ${ }^{98}$.

$Z$ innej strony przyznanie tytułu Człowiek Pogranicza wyraźnie podkreśliło ten fakt, że recepcja Osadczuka w Polsce jest dużo głębsza niż na Ukrainie. Jak trafnie zauważył badacz literatury i tłumacz Jurij Prochaśko, warto zastanowić się nad przyczynami wyjątkowej dysproporcji:

[...] między skalą osobowości Osadczuka i jego znaczeniem w najnowszej historii europejskiej a mizernym zrozumieniem w państwie ukraińskim. Tyle że wyjaśnienie tego jest wyjątkowo trudne, podobnie jak na ogół ciężko jest pojmować rozumem absurdalne zjawiska. $Z$ całą pewnościa dałoby się uzbierać cały szereg całkiem zadowalających wyjaśnień tych zjawisk, ale wątpliwe, by rzeczywiście złagodziły poczucie bolesnej niesprawiedliwości, a co więcej - goryczy $z$ powodu tego, że sami tak chętnie pozbawiamy siebie wielu rzeczy ${ }^{99}$.

Dużo jeszcze należy zrobić, aby zmienić tę sytuację. Potrzebne sa realistyczne, nieśpieszne, szczegółowe badania nad życiem i spuścizną Bohdana Osadczuka na poziomie dysertacji i monografii. Poczyniono w tym kierunku dopiero pierwsze kroki. Warto przetłumaczyć na język ukraiński jego prace naukowe oraz najważniejsze teksty publicystyczne i dziennikarskie, opatrując je odpowiednimi fachowymi komentarzami i aparatem krytycznym. Teksty te, ze względu na erudycję ich autora, jego umiejętność analizy konkretnych sytuacji i ich mistrzowskiej konceptualizacji oraz zdolność przewidywania przebiegu wydarzeń, stały się wartościowymi „kamykami” w majestatycznej intelektualnej mozaice życia politycznego Europy i świata w połowie lat pięćdziesiątych i na początku XXI wieku Noblista Czesław Miłosz, mówiąc o Osadczuku, stwierdził: „Przykładem swego życia dowodzi, że uparte trzymanie się jednej sprawy dostarcza nici przewodniej w chaosie historycznych wydarzeń"100.

Należy uczynić wszystko, aby lekcje płynące $z$ działalności Bohdana Osadczuka, jego dorobek, który służy m.in. pojednaniu polsko-ukraińskiemu, stały się aktualną i organiczna częścią współczesnego dyskursu naukowego, politycznego i społecznego na Ukrainie.

Przełożył z ukraińskiego Andrij Saweneć

\footnotetext{
98 K. Czyżewski, Linia powrotu, Wydawnictwo Pogranicze, Sejny 2008, s. 14.

99 Û. Prohas'ko, Don Kìhot iz Kolomï̈, w: Ukraiński polonofil. Pamięci Bohdana Osadczuka..., s. 61 .

${ }^{100}$ Cz. Miłosz, Słowo wstepne, w: B. Osadczuk, Ukraina, Polska, świat..., s. 7.
} 